
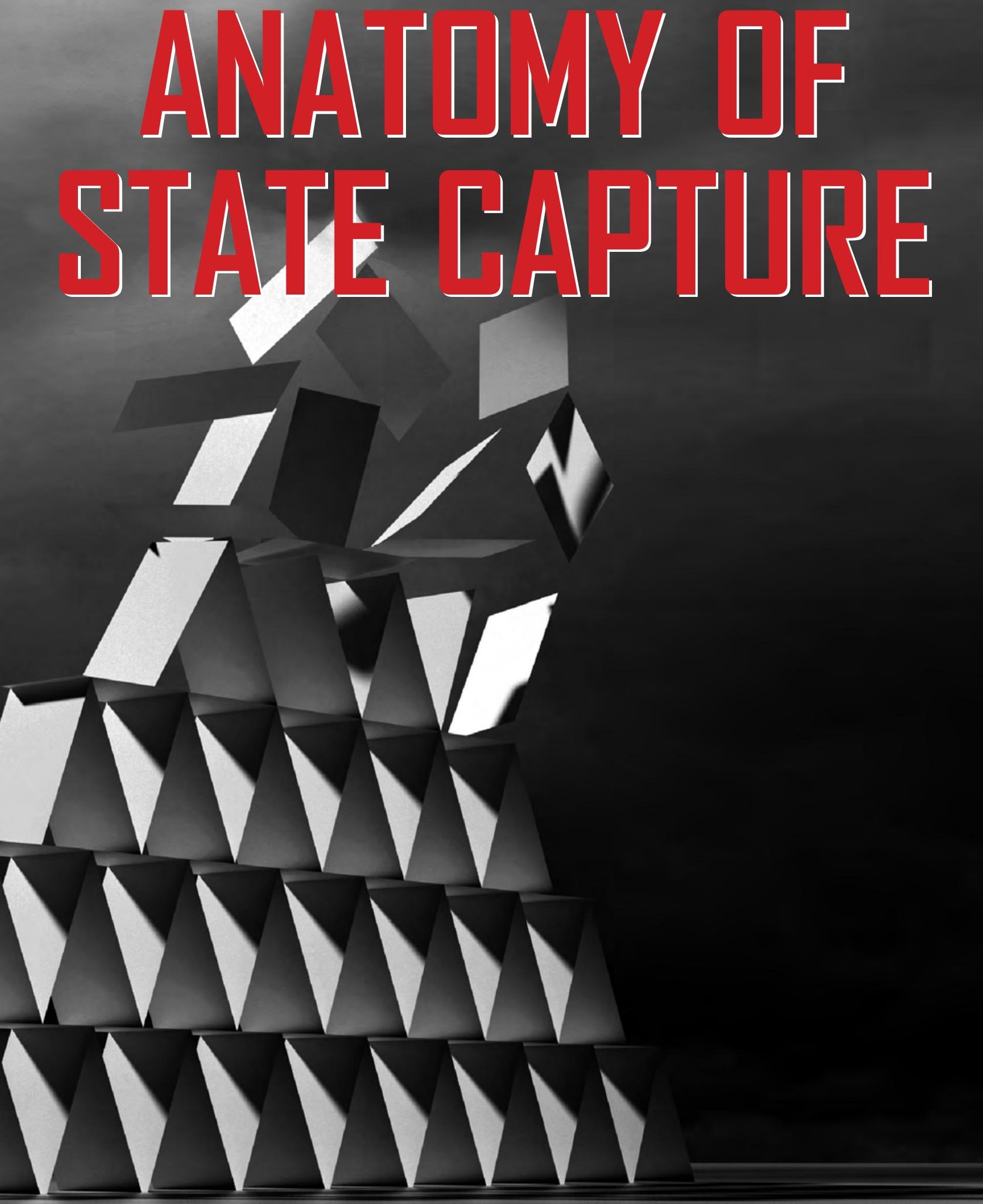

Nina Callaghan, Rabyn Foley and Mark Swilling (EDITuRS) 


\section{HOW STATE CAPTURE WENT NUCLEAR}

Dzvinka Kachur

\subsection{INTRODUCTION}

South Africa's nuclear deal has been described as one that would have bankrupted the country if it had not been forestalled by National Treasury in 2016 and overruled by the Western Cape High Court in April 2017. The building of a facility to produce 9.6 gigawatts $(\mathrm{GW})$ of nuclear energy would have constituted the single largest public infrastructure procurement programme in the history of South Africa, valued at an estimated R1tn, if not more (Gordhan, 2018; Nene, 2018). Thanks to the efforts of two women anti-nuclear activists, Makoma Lekalakala of Earthlife Africa Johannesburg (ELA Jhb) and Liz McDaid of the Southern African Faith Communities' Environment Institute (SAFCEI), who took the matter to the High Court, the nuclear deal was stopped.

In most countries, nuclear energy programmes are historically tightly connected to nuclear weapons programmes and unaccountable budgets (Fig, 2010; Locatelli, 2018; Wealer, Bauer, Göke, Von Hirschhausen \& Kemfert, 2019). With the global shift towards peaceful nuclear programmes, most notably after the Chornobyl disaster in 1986, the emphasis shifted towards the need for robust public participation and following of due process in nuclear-related procurement and implementation processes (IAEA, 2011). The South African nuclear deal was legally thwarted on these two counts.

The following analysis of the nuclear deal reveals the institutions, processes and people who worked to uphold the rule of law and keep the tenets of democracy alive. A debt is owed to the in-depth investigations undertaken by journalists, nongovernmental organisations (NGOs), the Public Protector's State of Capture report (2016), the State Capacity Research Project's Betrayal and the Promise (Bhorat, Buthelezi, Chipkin, Duma, Mondi, Peter, Qobo \& Swilling, 2017) and the South African Council of Churches' (SACC's) Unburdening Panel (2017), which provides a safe space for reporting incidents, amongst other actors and organisations. The roles played by South Africa's courts, robust energy and nuclear regulatory frameworks, 
finance processes and civil society are encouraging indicators that this country's democracy is underpinned by substantial checks and balances that are enduring and have not been corrupted. This is promising given that the prospect of nuclear energy in the national energy mix persists.

\subsection{BACKGROUND AND CONTEXT}

\subsubsection{Nuclear Energy in South Africa Pre-2009}

Nuclear energy is one of the oldest energy industries in South Africa. The country was a founding member of the International Atomic Energy Agency (IAEA) in 1957, although its membership was suspended in the apartheid era and only extended again in 1995. South Africa also operates the only nuclear power station on the African continent, which opened in 1984. The 1.8 GW Koeberg plant in the Western Cape province provides $5 \%$ of the electricity supplied to the national grid.

During the apartheid era (1948-1994), the nuclear industry grew under cover of the National Party's (NP) weapons programme and, to a lesser extent, from the country's desire to establish energy independence after suffering an oil embargo in 1973 and growing internal social unrest towards the end of the 1970s (Fig, 2010; Martin \& Fig, 2015; Kantey, 2017). Given the association with the military, the culture around the nuclear industry was secretive and conspiratorial. There was little public knowledge of the industry.

It is challenging to communicate to the general public about nuclear technology because of its highly technical nature and the invisible risks that it presents (Chernobyl Forum, 2006). The industry also tends to involve only a small circle of highly skilled employees on long-term employment plans. This often results in top-down planning that takes place without public consultation and in which technicians and government officials can make costly decisions with no accountability. Global experience of the industry illustrates that manufacturers of nuclear technology are at high risk of being drawn into corrupt activity and are regularly embroiled in scandals (Tanter, 2013).

The apartheid NP voluntarily closed its nuclear weapons programme and dismantled the weapons in 1989 (Fig, 2010). While the ANC had opposed nuclear power development prior to independence in 1994 (Fig, 2010), in 1996, the first democratic President Nelson Mandela's administration launched a broad public debate around the energy policy and peaceful use of nuclear energy (Fig, 2010). During this period, a group of skilled nuclear scientists approached a faction of ANC leaders to lobby for continuing nuclear research to save the rare skills in the country (Fig, 2010; Kantey, 2017). As a result of that lobbying, government agreed to support the Pebble Bed Modular Reactor (PBMR) project, which had been an attempt to develop a small-scale nuclear reactor 
(Kantey, 2017). It became a state-owned enterprise (SOE) in 1999, but government officially stopped investing in 2010 (Fig, 2010). In 2015, however, when Brian Molefe became Eskom CEO, the project was funded again from a pre-allocated research budget (Yelland \& Potgieter, 2017). And in January 2020, an expression of interest was issued to explore interest from the private sector in taking the PBMR project completely out of Eskom's care.

Many individuals have played key roles in the nuclear industry from the apartheid era nuclear weapon projects through to the launch of the PBMR project and the nuclear programme under the Presidency of Jacob Zuma (2009-2018) (Kantey, 2017). Amongst them are lobbyists Kelvin Kemm and Dave Nichols.

The ANC tried to transform the predominantly white nuclear industry by appointing more race- and gender-diverse employees (Fig, 2006). Scholarships were provided to train young South African nuclear scientists through initiatives such as the Eskom Nuclear Project 100. The opening of the sector failed, however, to change its secretive and non-transparent character. Nuclear-related companies were also opened to black economic empowerment shareholders, which resulted in the creation of vested interests and further division within the ANC, as well as confrontation between the nuclear lobby and anti-nuclear groups (Rennkamp \& Bhuyan, 2016).

Thabo Mbeki, President of South Africa from 1999-2008, stopped broad public conversation around the use of nuclear energy, ${ }^{1}$ resulting in a better coordinated and stronger anti-nuclear coalition (Kantey, 2017; McDaid, 2019).

In 2003, the NGO Earthlife Africa challenged the approval of the environmental impact assessment undertaken for the demonstration model of the PBMR (Western Cape High Court, 2005; Death, 2006). The NGO went to court in 2006, asking for disclosure of Eskom Board meetings related to the PBMR (Fig, 2010; McDaid, 2019). When the project closed in 2010, it had cost taxpayers more than R9bn for a project riddled with accusations of corruption and inadequate public participation that had never actually produced a demonstration model (Fig, 2010).

Growing demand for energy and severe disruptions to electricity supply in $2007 / 8$ put pressure on government to investigate and pursue different energy options. The expansion of nuclear energy capacity had always been on the table. In January 2007, the

1 Public participation for the Nuclear Energy Act (1999) and the National Nuclear Regulatory Act (1999) was only extended to members of the Chamber of Mines, representing the larger mine owners. The National Radioactive Waste Management Policy and Strategy did not accommodate public comments and the content of public participation engagements around South Africa's 2007 Nuclear Energy Policy and Strategy were never acknowledged, nor made public. 
Eskom Board announced its plan to construct 12 nuclear reactors that could generate $20 \mathrm{GW}$ to grow the country's overall electricity capacity by 2025 (Eskom, 2007). The Department of Minerals and Energy (DME) approved the new nuclear policy in 2008 (Department of Minerals and Energy, 2008), with much talk about job creation and socio-economic development through uranium mining and construction and operation of the plants.

Government explored offers from two companies: Areva, a French company, and Toshiba's Westinghouse from the United States (US), which owned shares in the PBMR project. Both options were too expensive (Department of Public Enterprises, 2008). Despite this, Director-General of the Department of Public Enterprises (DPE), Ms Portia Molefe, stated, "the South African government remains committed to introducing nuclear, because we have to deal with our carbon footprint, and we have to diversify our energy mix" (Department of Public Enterprises, 2008). It was suggested that the government explore new opportunities for nuclear development using a "strategic equity partner" (Eskom, 2009, p. 16). A new large-scale nuclear programme was presented in the 2010 Integrated Resource Plan (IRP) and approved in May 2011 (Department of Energy, 2011). The plan proposed the addition of $9.6 \mathrm{GW}$ of nuclear energy in the energy mix by 2030 to mitigate risks to the security of supply (Department of Energy, 2011).

The IRP is a key energy planning process that guides decision-making about the choice of technology, planning and implementation timeframes based on expected energy demand and dictates investment and infrastructure decisions (Department of Mineral Resources and Energy, 2019).

The Department of Energy (DoE) prepares the draft IRP with Eskom and energyintensive users (Montmasson-Clair \& Ryan, 2014). It integrates energy policy priorities such as a low carbon trajectory, job creation and poverty alleviation strategies and sets different limitations, such as those on coal imports or caps on levels of renewable energy. The public participation process is critical to ensuring transparency around targets and limitations, which otherwise can manipulate outcomes. The 2010 IRP was made available for public comment and 5090 specific comments were received, resulting in an increase in nuclear costs by $40 \%$ (Department of Energy, 2011).

The nuclear programme developed quickly. On 15 September 2011, the Minister of Energy, Ms Peters, announced that the proposal for the rollout of new nuclear power plants had been "signed off", was expected to be finalised by the end of 2011 and that the bidding process was expected to begin in 2012 (Flak, 2011). According to the Minister, Eskom would manage and operate the nuclear process, while the private sector would undertake the construction of the nuclear plants. At that time, 
it appeared that implementation of the nuclear programme would be a quick and easy process, but the costs, lack of transparency regarding decision-making and lack of inclusive public dialogue about the nuclear strategy became critical challenges that caused delays to the implementation and resulted in a court case.

\subsubsection{Symbiotic Visions of Zuma and Putin}

Following the approval of the 2010 IRP, the presence of the Russian nuclear industry grew in South Africa. Rosatom, the Russian State Atomic Energy Corporation, joined the South African Nuclear Industry Association (NIASA) as a member-sponsor in March 2012. In June 2012, its Rusatom Overseas Joint Stock Company, responsible for international nuclear construction projects, signed a memorandum of understanding with the South African Nuclear Energy Corporation (NECSA) to undertake joint business projects in the fabrication of nuclear fuel, manufacturing of power equipment for nuclear power plants, production of radioisotopes and marketing (Pressservice of JSC Rusatom Overseas, 2012). Rosatom opened a marketing office for sub-Saharan Africa in Johannesburg in July 2012; its third overseas office after the strategic decision was made in early 2012 to roll out 20 offices to improve international cooperation (Rossiyskaya Gazeta, 2012). Rosatom, which is a $100 \%$ SOE, serves as a vehicle for promoting the Russian nuclear industry. It is associated with regular corruption scandals involving top management, which provides evidence to support the notion that Rosatom is a critical player in Putin's elaborate neo-patrimonial network (Slivyak, 2019).

Russia felt politically supported in South Africa because President Vladimir Putin and President Jacob Zuma had developed a close relationship. Zuma had visited Russia for the first time in his official capacity in August 2010, a year into his Presidency, when then Russian President Medvedev offered South Africa the opportunity of "building nuclear power plants, [and] of joint exploration and development of uranium deposits" (Kremlin, 2010). With the acceptance of South Africa into the BRICS group of countries, the relationship between the two countries deepened. Zuma visited Russia at least seven times during his Presidency, which was unprecedented for a South African President. ${ }^{2}$ Mandela and Mbeki had visited Russia only once during their terms of office. ${ }^{3}$ In return, Putin visited South Africa in March 2013 (BRICS Summit) - Putin and Zuma met more than five times at other BRICS summits. ${ }^{4}$ According to

2 State visits: August 2010 and 2011, May 2013 and August 2014; G20 Summit in Russia September 2013, for Victory Day - May 2015; and as part of BRICS meeting in July 2015.

3 Mandela in April 1999 and Mbeki in July 2006, as part of the G8 meeting where South Africa was invited for consultations.

4 April 2010 in Brazil; April 2011 in China; March 2012 in India; July 2014 in Brazil; October 2016 in India and September 2017 in China. 
press statements, the nuclear programme formed part of the conversation during all bilateral meetings.

Zuma and Putin appeared ideologically close. Like many other ANC cadres, Zuma and Mbeki had trained in the Soviet Union during the apartheid era and had ideological and emotional connections to Russia (Shubin, 2008; Filatova and Davidson, 2013).

The South African newspaper, The Citizen, claimed that the connection between the two Presidents was secure because "they worked together in the 70s and 80s during the apartheid years when Zuma rose to be the head of intelligence for Umkhonto weSizwe, and Putin gained increasing access to the levels of power in Russia's highly feared intelligence service, the KGB" (Cilliers, 2016). During his interview with Business Day, Zuma explained his understanding of the South Africa-Russian relationship as: "They would not come for us. They would understand, we would have an agreement to work out another arrangement. We know they [Russia] are trusted people. We know they will never sink us; they will lift us" (Maughan, 2019). Both Zuma and Putin openly used anti-west rhetoric differentiating the west from Russia and China in their support for the "real development" of African countries.

In addition, both Putin and Zuma were Presidents with legacy on their minds. Zuma was intent on radical economic transformation, and nuclear energy seemed like the best option for solving South Africa's severe energy scarcity challenge and ensuring that black people owned and controlled significant assets and supply chain in the industry. Going further, South Africa could become a leader in promoting nuclear energy on the continent, an idea that had been actively promoted by NECSA and other state officials during the PBMR project (Kantey, 2017). Zuma also had a more pragmatic interest in promoting nuclear energy as it would ensure that his family and their proxies gained economically from uranium mining (Gosam, 2017; Wa Afrika, Jika \& Skiti, 2017).

The Gupta-linked company Oakbay purchased the non-operational uranium mine Dominion (renamed Shiva) on 14 April 2010. The state-owned Industrial Development Corporation (IDC) provided $90 \%$ of the purchase price for the mine (R250m) (amaBhungane, 2014). A minor shareholder in Shiva mine was Duduzane Zuma, son of President Zuma. Oakbay was meant to repay the funds in 2013, but the IDC opted to receive 3.6\% shares in the mine instead (amaBhungane, 2014; Gosam, 2017). The IDC is now attempting to recover their investment through the courts (Sidimba, 2020).

For Putin, building a nuclear fleet in South Africa and regaining the geopolitical influence lost after the collapse of the Soviet Union would support the rebuilding of 
"great Russia". ${ }^{5}$ Putin has a long track record of using traditional energy resources (gas and oil) for political gains (Gonchar, Chubyk, Dyachenko, Ishchuk, Lakiichuk, Hychka \& Mukhrynsky, 2017). The experience of nuclear power plant construction in Turkey and in some other countries illustrates how Russia is able to convert these projects into political gains (Nakano, 2020).

Exporting nuclear technology would generate economic benefits and satisfy both priority areas of Russian interest in Africa: international influence and access to mineral resources (Arkhangelskaya \& Shubin, 2013). Western observers have criticised Kremlin-backed nuclear initiatives, describing them as a means for Russia to create energy dependencies and establish a semi-permanent foothold in Africa (Burke, 2019; Hairsine, 2020).

Multiple sources have suggested that 2013 was the most critical year for Zuma and Putin's agreement about the nuclear deal (Hunter, 2014; Wa Afrika, Jika \& Skiti, 2017). As Putin himself explained in March 2013, "[i]n Durban, we reached agreements that were important for our bilateral relations" and in May 2013 in Sochi "[discussed] how to practically implement them" (Putin, 2013). The negotiations manifested in the signing of the intergovernmental agreement in 2014. The timing of the announcement coincided with Zuma's State of the Nation Address (SONA) in February 2014 at the annual opening of Parliament. Zuma mentioned nuclear energy for the first time since 2009, stating, "We expect to conclude the procurement of $9600 \mathrm{MW}$ [9.6 GW] of nuclear energy" (Zuma, 2014). He kept up the rhetoric in the following year's address, setting a target for the first new nuclear grid connection by 2023, stating that it would be "just in time for Eskom to retire part of its aging power plants" (Zuma, 2015). 2014 was also the year in which mention of renewable energy procurement disappeared from SONA speeches.

Testimony at the Zondo Commission by Nhlanhla Nene has shown that the nuclear deal was directly negotiated between Zuma and Putin (Zondo Commission, 2018b), while Pravin Gordhan has stated that the nuclear deal was personally driven by Zuma (Gordhan, 2018). According to Mcebisi Jonas, Zuma was exerting "immense pressure" to get it approved (Zondo Commission, 2018a, p. 30).

\subsection{WHAT'S REQUIRED TO GET NUCLEAR?}

The procurement of energy in South Africa is highly regulated and nuclear programme implementation requires significant coordination of efforts across multiple governing institutions (see Figure 16.1 on p. 339). The quality of the governance is ensured by

5 The concept of great Russia is described in multiple works of Aleksandr Dugin and had a strong impact on Putin during his first terms in power. 
splitting functions such as licensing, procurement and control between different governmental institutions. There are also mechanisms of accountability built in via public participation processes and Parliament's oversight role.

The Electricity Regulation Act (Republic of South Africa, 2006), Nuclear Energy Policy (Department of Minerals and Energy, 2008), National Development Plan (2012) and IRP 2010 provide the legislative framework for the nuclear industry in South Africa (Prins, 2018). Figure 16.1 illustrates a simplified governance and regulatory structure for the sector.

The Minister of Energy ${ }^{6}$ plays the most critical role because only she/he can issue a Section 34 Determination that specifies how much energy of each source is procured, based on the IRP (Republic of South Africa, 2006). The Minister of Energy also coordinates the authorities that set the "rules" for the nuclear programme (Prins, 2018):

a. The National Energy Regulator of South Africa (NERSA) regulates the energy industry and ensures licensing, monitoring, performance and compliance.

b. The National Nuclear Regulator is responsible for nuclear safety.

c. NECSA is mandated to undertake and promote research and development in the field of nuclear energy.

As the Minister of Energy is responsible for both promoting and regulating the nuclear industry, s/he is vulnerable to conflict of interests (IAEA, 2013).

The Minister of Public Enterprises oversees the SOE Eskom, the institution defined by energy policy as the owner of nuclear power plants. State ownership in nuclear power plants must be at least 50\%, and energy needs to be procured based on the principles of fairness, equitability, transparency, competitiveness and cost-effectiveness. Permission from the Minister of Finance/the National Treasury is required for procurement.

The Minister of Finance provides the final approval for public capital expenditure, state guarantees and the procurement process. Parliament bears final oversight of the procurement, licensing and regulation of nuclear energy, with public participation taking place at different stages.

The Minister of Environment is responsible for environmental Impact assessments, the mechanism that allows for public participation, and which was used by civil society to oppose the rollout of the nuclear energy programme (Kantey, 2017; McDaid, 2019).

6 Responsibility for South Africa's energy policy was allocated to Department of Minerals and Energy (DME) from 2004-2009; Department of Energy (DoE) from 2009-2019 and Department of Mineral Resources and Energy (DMRE) from 2019 onwards. 


\section{GOVERNANCE STRUCTURE OVERSEEING NUCLEAR ENERGY PROCUREMENT}
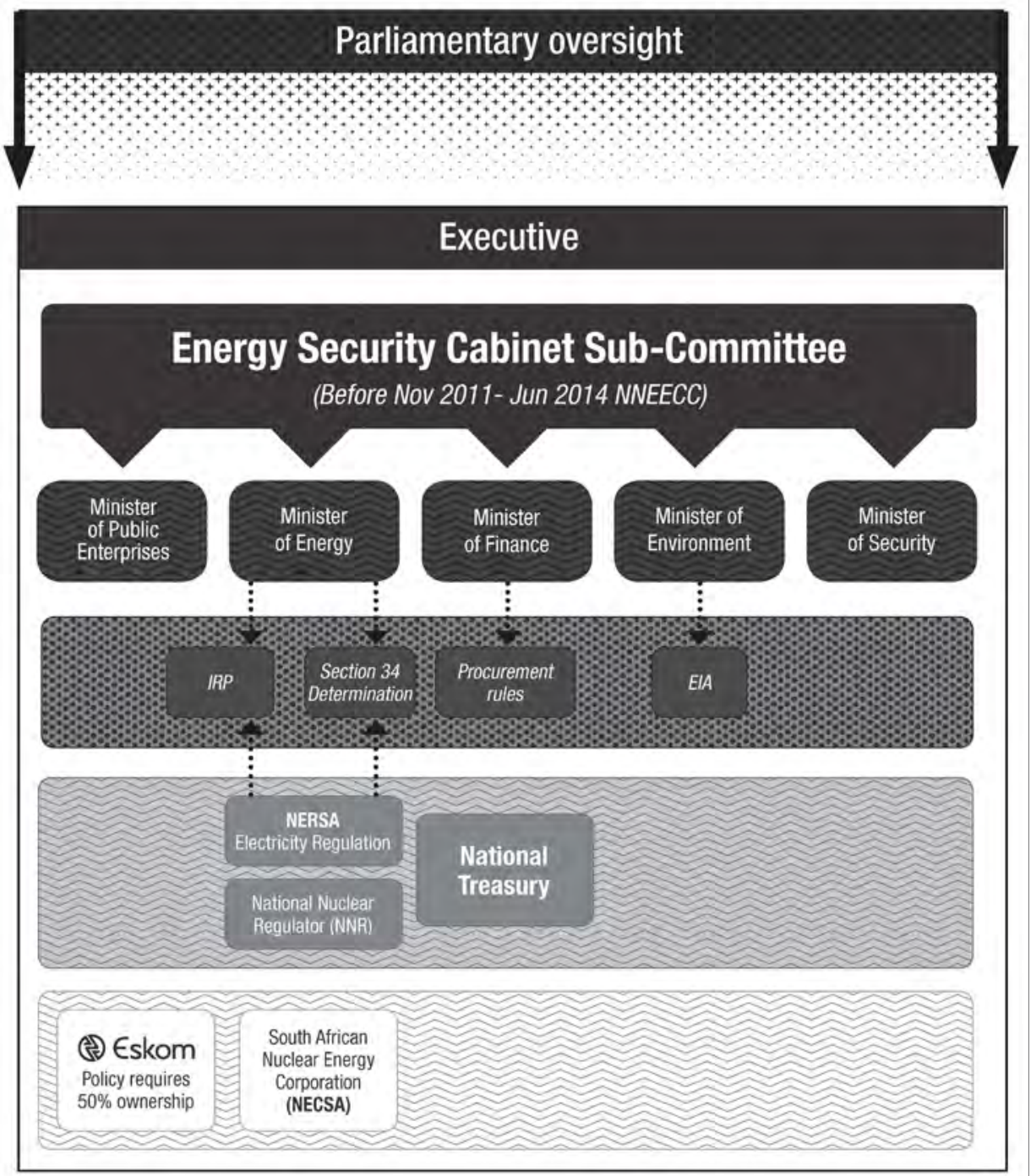

\section{UNIVERSAL GRAPHICS KEY}

Policies \& processes
Regulatory authorities

Public Companies, SE0

FIGURE 16.1 Organisational structure of South African institutions managing nuclear energy

The following section describes the breakdown in governance structures that allowed personal interests to operate in secret, manipulate and ignore policies and create 
parallel processes, all the while disregarding the financial and development risks that the proposed deal held for South Africa.

\subsubsection{Creating Unaccountable Structures: National Nuclear Energy Executive Coordination Committee/Energy Security Cabinet Subcommittee}

On 9 October 2011, Cabinet established the National Nuclear Energy Executive Coordinating Committee (NNEECC) within the Presidency to "ensure implementation and exercise oversight over all aspects of this nuclear energy policy" (Department of Minerals and Energy, 2008, p. 22). This structure was established to coordinate efforts but was used instead to hide nuclear programme processes from the public and from Parliament.

Deputy President Kgalema Motlanthe, a loyal Zuma supporter, chaired the NNEECC when it was established. But in April 2013, Zuma claimed the position - he had in any case been acting as chair and officials sometimes "would be invited to two separate meetings, one chaired by Motlanthe and another chaired by Zuma" (Fin24 and City Press, 2014). Later, in an interview in November 2015, Motlanthe criticised Zuma for not following the Constitution, stating that in the nuclear discussion there is "a monopoly in the realm of ideas, or you have people who have a consensus even before they discuss any subject matter..." (Mkokeli \& Marrian, 2015). The NNEECC had several technical committees, the names of members were not disclosed to the public or to Parliament.

Former Finance Minister Pravin Gordhan suggested in his statement to the Zondo Commission that the NNEECC was established because "former President Zuma wished to procure $9.6 \mathrm{GW}$ of nuclear power generating capacity for South Africa from Russia" (Gordhan, 2018, p. 16). The lack of transparency regarding the functions, structure and work done by the NNEECC led to diminished public and industry trust in government, making the committee just one of the examples of unaccountable structures that undermine collective political institutions (Bhorat, Buthelezi, Chipkin, Duma, Mondi, Peter, Qobo \& Swilling, 2017).

\subsubsection{A Reason to Pursue It: The IRP}

The IRP itself posed the first challenge to implementation of the nuclear deal. The IRP goes through extensive public participation and approval processes. The IPR 2010 approved the procurement of 9.6 GW of nuclear energy. The Minister of Energy must refer to the IRP when issuing the S34 Determination to procure energy. The IRP is designed as a "living plan" because energy technology develops extremely fast. It is meant to be reviewed biannually. The IRP 2010 was thus due to be reviewed in 2012 
(Department of Energy, 2011), but it took nine years for the next iteration to be gazetted in October 2019. This delay left open a window for nuclear implementation, despite the advances of alternative energy technologies during this time.

Provision had been made in the IRP 2010 for the Renewable Energy Independent Power Procurement Programme (REIPPP). The process got underway between 2011 and 2013 in procuring $2400 \mathrm{MW}$ of renewable energy from independent power producers (Martins, 2013). Renewable energy is a fast-changing technology and during the Window 3 procurement on 4 November 2013, the prices for renewable energy had already dropped from 202 ZARc/kilowatt hour (kWh) to $70 \mathrm{ZARc} / \mathrm{kWh}$ (Eberhard \& Naude, 2017). When this new pricing was included in the draft update for the 2013 IRP model, the model indicated that the nuclear power decision could be delayed until 2025 or even post-2035, and "that alternative options, such as regional hydropower and shale gas, could fulfil the requirements" (Department of Energy, 2013, p. 8). The draft IRP 2013 was never approved by the Cabinet, and no comments were made as to why the process went silent. This conflict between renewable and nuclear energy defined the development of both industries over the next seven years as well as the energy discourse post-2017 (Kachur \& LeRoux, 2021).

To address the conflict between the renewable and nuclear energy industries and to speed up the signing of the intergovernmental agreement with Russia (explained further), the NNEECC was transformed into an Energy Security Cabinet SubCommittee (ESCS) in June 2014. This expanded its mandate to oversee the development of South Africa's future energy mix (Zuma, 2014).

Zuma chaired the ESCS, which included the Ministers of Energy, International Relations and Cooperation, Public Enterprises, Finance, State Security, Trade and Industry, Economic Development, Mineral Resources, Environmental Affairs and Defence. The Committee was responsible for all decisions and information with regards to feasibility studies, different aspects of technology and assessment of submissions for requests for proposals, and determination of the owner and operator of the new nuclear fleet. Gordhan, in his statement to the Zondo Commission, encouraged the Commission to "investigate the rationale for these changes and the activities undertaken by the ESCS in advancing 'the nuclear deal'” (Gordhan, 2018, p. 21).

All information about the agenda and documents of the NNEECC and ESCS were classified under the Minimum Information Security Standard Act (1996), designated as top secret and even kept from the Parliamentary Committee on Energy (The Presidency, 2015b). As Zuma controlled these institutions, he was able to prevent Eskom, government Ministers and Parliament from having any technical oversight or access to information regarding the nuclear deal. 


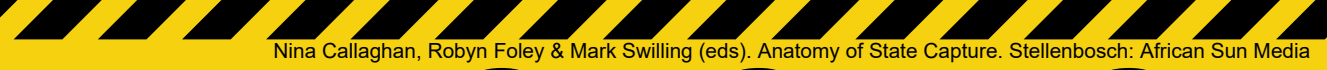 \\ THE TOXIC NUCLEAR THAT NEARLY COST SA TRILLIONS}

\section{UNIVERSAL GRAPHICS KEY}

Disasters

Interactions with Russia

Questionable interests
In the public's interest

Shadow State Power Elite

State energy concerns

i9i No public participation

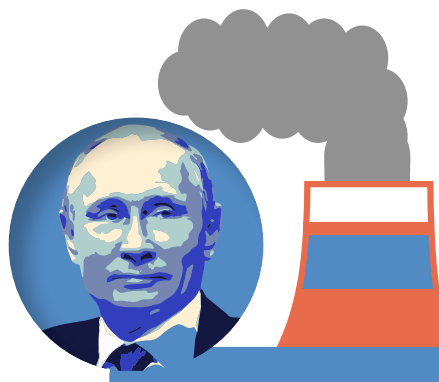

\section{Jacob Zuma}

Trained in the Soviet Union during apartheid, Zuma developed close ideological and political affinity with Russia \& Putin. He visited Russia seven times during his presidency, pushing the Nuclear Deal to cement this bond regardless of cost.

\section{Tina Joemat-Pettersson}

Staunch Zuma supporter, Joemat-Pettersson is appointed Minister of Energy by Zuma in 2014 (despite 2 prior scathing Public Protector findings against her). She oversees much of the Nuclear Deal's unconstitutional processes including signing the second Determination 34.

\section{9}

SA dismantles its nuclear weapons.

$$
1
$$

\section{3}

To retain \& develop local nuclear energy IP/capabilities the Pebble Bed Modular Reactor (PBMR) project is started.

\section{8}

After bids from Areva (France) \& Westinghouse (US), nuclear option is deemed too expensive. (Rosatom not selected as a preferred bidder).

\section{9}

PBMR becomes a State-0wned Enterprise (SOE).

\section{7}

Eskom board announces plans to construct 12 nuclear reactors to grow the country's overall electricity capacity with +20 GW by 2025 .

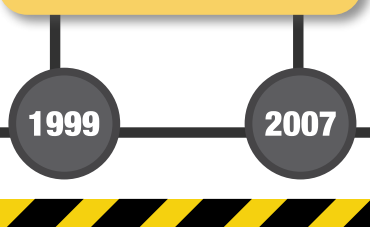




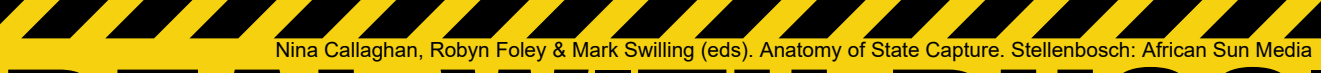

DEAL WITH RUSSIA

\section{AND LAID THE

9.6 GW of nuclear energy approved by 2010 IRP, to be operational by 2030. Same IRP also approves the 2.4 GW Renewable Energy Independent Power Procurement Programme (REIPPP) delivered by independent power producers.

\section{Fukushima nuclear disaster.}

National Nuclear Energy Executive Coordinating Committee (NNEECC)

- established to coordinate efforts.

Minister Peters announces roll-out of nuclear power plants.

Russia opens Rosatom office in Johannesburg.

\section{(1)}

Nuclear Deal "principal agreement" reached during Putin's SA visit for

\section{1}

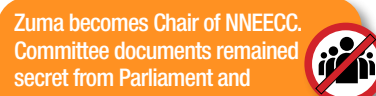

\section{I}

Zuma visits Russia (Sochi)

"to discuss practical steps" of Nuclear Deal.

Inta

Zuma visits Russia to attend G20.

I

2013 IRP draft updated

but not approved

Cost of renewable energy (RE) drops from 202 ZARc/kilowatt hour (kWh) to 70 ZARc/kWh. Suggestions to delay nuclear until 2025 in draft IRP.

\section{IIII}

Intergovernmental Agreement (IGA) with Russia is ready but National

Treasury won't sign without feasibility study.

\section{InI}

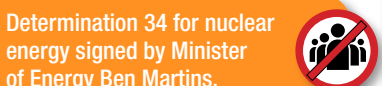

of Energy Ben Martins.

(Only disclosed in Dec

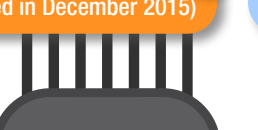

2013

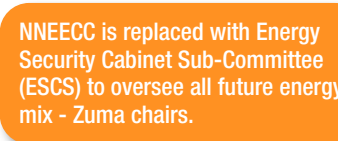

1

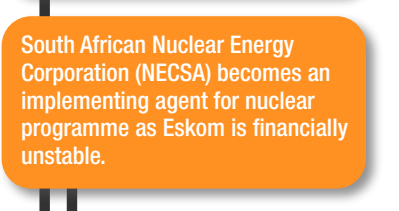

Zuma visits Russia for "medical"

reasons - returns with the

negotiated details of Nuclear Deal.

11

New Minister of Energy Tina

Joemat-Pettersson signs IGA

on Strategic Partnership \&

Cooperation in the Fields of

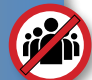

\section{1}

Zuma visits Russia to celebrate

WWII, Victory Day.

\section{Han}

Joemat-Pettersson tables
agreement with Russia as
non-technical \& non-binding,

avoiding parliament \& public debate.

Zuma visits Russia for BRICS

meeting \& asks Minister of Finance

Nene to sign the state guarantee

with Russia without the feasibility

study. Nene refuses.

\section{1}

Eskom CEO Brian Molefe refuses to

REIPPP plants \& pushes nuclear.
R

\section{11}

Anti-nuclear activists, Makoma Lekalakala of Earthlife Africa

Johannesburg (ELA-JHB) \& Liz

McDaid of the Southern African

Faith Communities' Environment Institute (SAFCEI), launch a High

Court case against government

to stop nuclear development

on grounds of irregular Russian

Nuclear Deal \& lack of public participation.

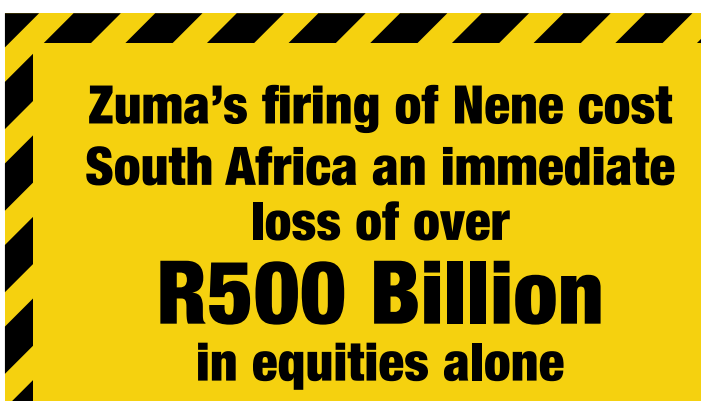

1

Mcebisi Jonas is offered R600m bribe by Gupta family to become 'their' Minister of Finance. He informs Nene.

\section{Nene Gate}

Zuma fires Nene, appointing Des

van Rooyen - financial market

responds, inflation rising from

R14.59 to R15.90. 3 days later

Zuma is forced to replace Van

Rooyen with Gordhan.

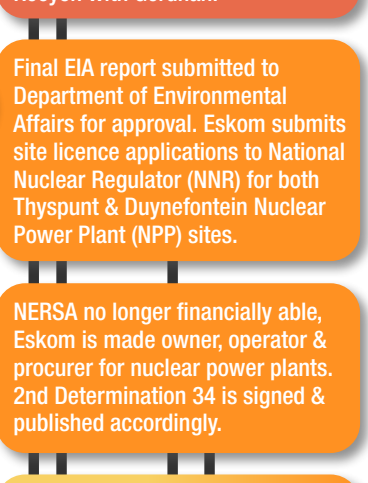

New IRP 2016 draft published for comments, but not approved by Cabinet.

II

Eskom announces Request For Proposals (RFP) for nuclear power plant (NPP) construction.

11?

Treasury withdraws authorisation for Request for Proposal (RFP) and tones it down to a non-binding Request for Information (RFI) instead.

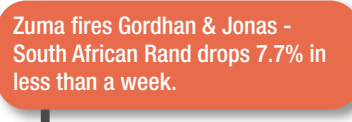

.

Nationwide mass protests demand Zuma leave office.

\section{1}

High Court rules the Nuclear Deal unlawful \& unconstitutional based on further findings of irregular approval processes.

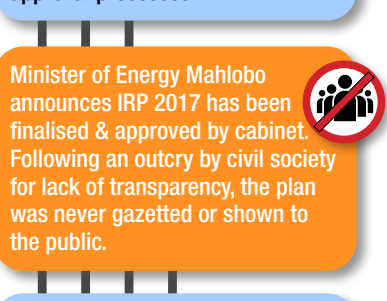

Zuma forced to step down as President - replaced by Cyril Ramaphosa.

Government publicly abandons plans to build $9.6 \mathrm{GW}$ nuclear.

\section{?}

Almost 10 years later the official, updated IRP 2019 is gazetted. New energy mix sees renewables increase to $6.8 \mathrm{GW}$ with coal still the primary energy source. Nuclear remains an option with plans for $2.4 \mathrm{GW}$.
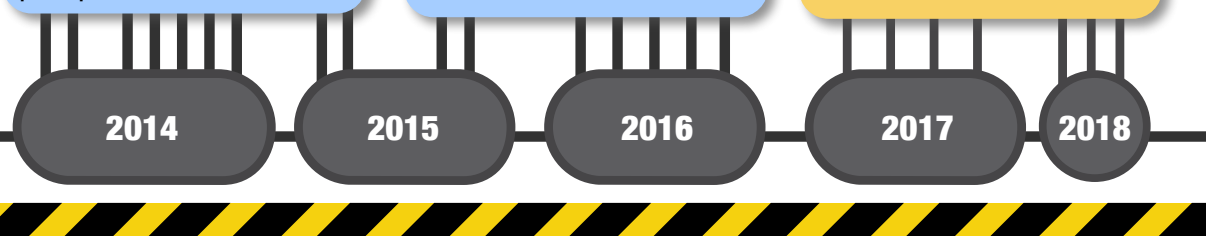


\subsubsection{Estimating the Costs of Nuclear Energy and Political Will}

Nuclear power projects, whether they are in the US, Russia or China, are tightly connected to the military sector and because they are hardly ever based on pure market principles tend to easily run over budget (Nakano, 2020). To finance these expensive projects, it is most common to combine state funding with private funds (Pehuet Lucet, 2018). In such situations, political commitment is critical. According to the head of Nuclear Infrastructure Development at the IAEA, new nuclear programmes require "broad political and popular support and a national commitment of at least 100 years" (Gil, 2018). South Africa lacked such a commitment.

The country's 2012 National Development Plan sets out the country strategy for South Africa until 2030 and it noted serious concerns about the development of nuclear energy and the need to "reassess the timing and/or desirability of nuclear power" (National Planning Commission, 2012, p. 172).

The DoE had invested R200m for "preparatory work" to conduct the feasibility study between 2012 and 2017; 80\% of this went to Central Lake Trading (trading as Empire Technology), owned by Shantan Reddy, the son of Zuma's friend Vivian Reddy (Department of Energy, 2015b). In December 2013 when the National Treasury received a draft feasibility study for the nuclear programme, it became apparent that, according to Nene's statement to the Zondo Commission, "regardless of the underlying policy rationale to develop nuclear energy capacity, the costs associated with it are astronomical" (Nene, 2018, p. 22). The estimate of costs differed significantly; for example, head of Rosatom Sergey Kiriyenko estimated the programme's total cost at between $\$ 40-50 \mathrm{bn}$, which would include "preferential" funding from the Russian state budget and up to $\$ 10 \mathrm{bn}$ in contracts for local companies (TASS, 2014). Then Minister of Finance Gordhan's ${ }^{7}$ estimate was around R1tn (Gordhan, 2018). When including the establishment of a local fuel supply, the building of waste facilities and the decommissioning plan, project costs would likely reach R1.4tn (Staff Reporter, 2015). The lack of clarity around the financial model made it impossible for the National Treasury to support the procurement process.

A successful nuclear programme requires long-term state commitment in terms of resources, policy and time because the process from initial conceptualisation to electricity production at maximum capacity, waste management and eventual decommissioning is both long and exorbitantly expensive. 


\subsubsection{Non-disclosure of Information that Should Be Available for Public and Parliamentary Oversight}

Despite the lack of support from the National Treasury and the fact that the draft IRP 2013 had suggested the postponement of the nuclear energy programme, it was approved. In December 2013, the key document for the procurement process - the S34 Determination for 9.6 GW of nuclear energy - was signed by then Minister of Energy Ben Martins and the Head of NERSA Ms Cecilia Khuzwayo (Department of Energy, 2015a). This document was not disclosed to the public for more than two years. It was finally gazetted on 21 December 2015, a few weeks after SAFCEI and ELA Jhb launched the court case against the programme based on the lack of public participation. There was no explanation given by government as to why this document had not been made public.

Pressure to sign the intergovernmental agreement on nuclear cooperation with Russia was growing. The agreement was ready for signing in November 2013 but disagreements with the National Treasury and the absence of the S34 Determination stopped it from going ahead (Western Cape High Court, 2015; Zondo Commission, 2018c). Then Minister of Energy, Ms Joemat-Pettersson, wrote to Zuma explaining the delay as due to "technical issues" that had not allowed her predecessor (Martins) to sign the agreement, but that these issues were finally resolved (Western Cape High Court, 2015). On 21 September 2014, Rosatom and Joemat-Pettersson signed the intergovernmental agreement On Strategic Partnership and Cooperation in the Fields of Nuclear Power and Industry (Republic of South Africa and Russian Federation, 2014). The parties issued a joint press statement in which Rosatom announced that they had secured the right to build the capacity for $9.6 \mathrm{GW}$ of nuclear power in South Africa (Department of Energy, 2014).

On 22 September, the Minister of Energy clarified that this was only one agreement and that similar agreements had and might be signed with other countries. Similar, but not legally binding agreements were signed with the US (2009); South Korea (2011) and later with China and France (2014). Nevertheless, the contents of the agreement with Russia were not disclosed to the public or Parliament until leaked by the EcoDefense, Russian environmental activists (Western Cape High Court, 2015; McDaid, 2019). The document outlines the structure of the Russia-South Africa agreement and indicates that Russian technology would be used exclusively for the construction of the 9.6 GW capacity against South Africa's constitutional requirements for open bidding. The agreement also proposed a tax exemption (Article 9) for the nuclear cooperation programme (Article 3 describes the design, construction, operation and decommissioning of nuclear power plants in South Africa). It also left space for the negotiation of the location and rollout of $7.4 \mathrm{GW}$ prescribing only the location of an initial 2.4 GW (Article 4) (Republic of South Africa and Russian Federation, 2014). 
On June 2015, the Minister of Energy bypassed legislative requirements by tabling the agreement instead of submitting it for approval by resolution as suggested by the State Law Advisor (Western Cape High Court, 2015). This example of non-disclosure to the public or Parliament of critical information has significant implications for the financial stability of the country and illustrates the secrecy surrounding the nuclear deal.

\subsubsection{The Implementing Agent: Stretching SOEs with Financial Obligations}

The door to procurement for the nuclear programme seemed to be open with the signed intergovernmental agreement, but new challenges arose from Eskom's financial instability. Eskom is defined as the owner of any nuclear power generation plants (Department of Minerals and Energy, 2008) and as the procurement agency in the S34 Determination signed by Minister Martins in 2013 (Department of Energy, 2015a).

Its financial situation had deteriorated in June 2014 and its Fitch rating revised from stable to negative (Eskom, 2014). Its debt was at more than R250bn (Mbatha \& Crowley, 2014) and the Eskom Board was forced to write to the DoE indicating its inability to commit to any funding beyond already existing commitments (Gordhan, 2018). NECSA became the implementing agent in June of that year "to mitigate delays with the nuclear programme" (PMG, 2016). Fuzile in his statement to the Zondo Commission noted that NECSA, predominantly a government-funded research institution, lacked financial soundness and implementing capacity (Fuzile, 2018).

Eskom management changed in 2015 with Brian Molefe appointed as CEO and Ben Ngubane as Board Chairman ${ }^{8}$ (Eberhard \& Godinho, 2017). The Board reported to the DoE in September 2015 that the financial situation of the company had improved and that it was capable of being the majority owner and operator for the nuclear programme. According to Joemat-Pettersson's presentation to Parliament, the funding for the procurement programme would come from Eskom's balance sheet (PMG, 2016). Molefe halted procurement of renewable energy within the REIPPP to remove any threat to the nuclear programm, and contracts during the Window 4 period remain unsigned until March 2018 when Cyril Ramaphosa came to power.

Cabinet approved Eskom as the owner-operator and procurer for nuclear power plants on 2 November 2016 in accordance with the 2008 Nuclear Energy Policy and approved NECSA as the procurer for the fuel cycle and multi-purpose reactor for the new nuclear fleet. In the same month, a new draft IRP 2016 was published for comment. It included building capacity for $1.4 \mathrm{GW}$ of new nuclear capacity by 2037 , 
and a total of $20 \mathrm{GW}$ (electrical) over the long term (Department of Energy, 2016b). This document included a number of manipulations, such as a cap on renewable energy (Wright, Bischof-Niemz, Calitz, Mushwana, Van Heerden \& Senatla, 2017) and it did not contain calculations of the least cost scenario (Levington, Van Dyk, Eberhard \& Bischof-Niemz, 2016). The Council for Scientific and Industrial Research noted that both least cost and uncapped decarbonised scenarios would result in cheaper, cleaner (fewer emissions and less water usage) energy that had the potential to create more jobs (Wright, Bischof-Niemz, Calitz, Mushwana, Van Heerden \& Senatla, 2017). After opening for comments, however, the IRP 2016 process went silent and was not signed or approved by the Cabinet.

On 14 December 2016, the second S34 Determination was signed for the full nuclear capacity of 9.6 GW with the adjusted ownership (Department of Energy, 2016a). But six days later, the National Treasury withdrew authorisation for the request for procurement and toned it down to a non-binding request for information instead to be handled by Eskom. The request for information asks countries that wish to bid as suppliers to answer questions on the localisation of construction and fabrication of the technology, training schemes, intellectual property sharing and exposure and other issues that form the basis of any large-scale construction programme.

\subsubsection{Securing Control: The Five Ministers of Energy, Manipulating the Process to Seal the Deal and Nene-Gate}

South Africa's President has the full authority to appoint or dismiss Ministers and Deputy Ministers. In what has become known as Nene-Gate, Zuma fired Finance Minister Nene in December 2015, apparently for his refusal to sign off on the nuclear deal and several other procurement deals relating to Denel and Transnet - two other SOEs that were heavily looted during the state capture period. Nene-Gate was the turning point in the nuclear deal and revealed to the public the National Treasury's opposition to Zuma, as well as unveiling an important player in the resistance to state capture - the country's financial markets.

In July 2015, Nene refused to sign the state guarantee to Russia without the feasibility study. He explained that for him, as a Minister of Finance, it was important to ensure "the secure, accountable, transparent, sound, effective and efficient management of the country's public finances, sovereign debt and the economy at large" (Zondo Commission, 2018b, p. 70). On 9 December 2015, Zuma fired Nene.

Just several hours earlier, Joemat-Pettersson had presented an outdated report to Cabinet on the cost estimations of the nuclear programme (De Lange, 2018), using an exchange rate of ZAR10/USD1 when the actual exchange rate was more than ZAR14/ USD1. On the same day, Zuma's Cabinet approved procurement of the $9.6 \mathrm{GW}$ 
nuclear programme. Cabinet decided not to disclose the cost of the project to the public (Gordhan, 2018).

Zuma appointed Des van Rooyen as Finance Minister, which led to an immediate reaction from the financial markets. In just 48 hours, the rand exchange rate grew from R14.59 against the US dollar to R15.90 (Bezuidenhout, 2019). This forced Zuma to replace Van Rooyen with a more acceptable choice for financial markets and within three days of Nene's firing, Pravin Gordhan was appointed Minister of Finance. In his media statement, Zuma explained that he had changed Ministers due to public concerns because he had "received many representations to reconsider" his decision (The Presidency, 2015a). In March 2017 when Zuma fired Gordhan and his deputy Mcebisi Jonas, rating agencies, such as Fitch Ratings, Moody's Investor Service and Standard \& Poor's, downgraded South African indexes as a direct response, according to Gordhan's statement to the Commission (Gordhan, 2018). This did not, however, influence Zuma's decision in this instance.

Nene-Gate also illustrated the different capacities for resistance between the ministries of Energy and Finance. Organisations dependant on decisions of the Minister of Finance, such as the financial markets, held significant political weight while organisations affected by decisions of the Minister of Energy did not. During Zuma's reign as President, there were five Ministers of Energy: Dipuo Peters (10 May 2009 to 9 July 2013), Dikobe Ben Martins (9 July 2013 to 25 May 2014), Tina JoematPettersson (25 May 2014 to 30 March 2017), Mmamoloko Kubayi (30 March 2017 to 17 October 2017) and David Mahlobo (17 October 2017 to 25 February 2018)9 (Van Onselen, 2017). The rapid cycling of Ministers did not evoke the same political and financial crisis as the removal of Minister Nene.

The officials cited in Sunday Times news articles on the topic suggest the direct involvement of the Russian Presidency in the dismissal of Minister of Energy, Ms Mmamoloko Kubayi. On her appointment, she had launched several investigations into irregularities in the nuclear tender process and had suspended high-level officials (Joubert, 2017). The Sunday Times, based on interviews with undisclosed officials, reported that during Minister Kubayi's visit to Russia in June 2017, she had refused to sign any commitments on the nuclear deal before the new IRP came out in February 2018. According to Sunday Times sources, the Russian representatives requested that Zuma replace her (Wa Afrika, Jika \& Skiti, 2017). In her place, Zuma appointed David Mahlobo, a former State Security Minister who was trained in Russia.

9 Their respective lengths of term in office cast some light on their utility to Zuma and should be read in conjunction with the obstacles to the nuclear deal discussed in this section. Peters: 4 years, 1 month and 8 days; Martins: 10 months and 24 days; Joemat-Pettersson: 2 years, 10 months and 29 days; Kubayi: 6 months and 16 days; Mahlobo: 4 months and 242 days. 
According to Forensics for Justice, Mahlobo in cooperation with Russian experts conducted illegal surveying of ANC members and other important personas in South Africa (Forensics for Justice, 2018). In his position as State Security Minister, he was believed to be the Russians' eyes and ears in the South African government. Mahlobo's loyalty to Russia is proven by his continued engagement with Russian counterparts even following the High Court's decision on 26 April 2017 to ensure that the procurement of 9.6 GW of nuclear energy remained an option (Mahlobo, 2017).

On 7 December 2017, after the fast organised Africa Energy Indaba, with invitations sent to the public just a few days before the event, Minister Mahlobo announced that the public consultation process was finalised and that the long-awaited IRP 2017 had been approved by Cabinet. Mahlobo stated that all energy sources would remain the same, but be reduced by $20 \%$ due to decreased demand (Joubert \& Magubane, 2017; Yelland, 2017). This statement caused an outcry from civil society organisations because of the lack of a public consultation process (Centre for Environmental Rights, 2017). Despite the Minister's statement and his reassurance to Parliament that the IRP was finalised (PMG, 2018), the plan was never gazetted or shown to the public. The Russian Embassy denied its involvement in South African politics (Kulyaev, 2017).

While Zuma managed to overcome a lot of obstacles in operationalising the nuclear deal, civil society organisations, with the support of media and justice institutions, delayed its implementation until Zuma ran out of time.

\subsection{DEMOCRACY AT WORK: CIVIL SOCIETY AND THE HIGH COURT}

Civil society resistance to the nuclear deal had reached new heights in October 2015, when Lekalakala and McDaid launched a legal challenge against the deal (Western Cape High Court, 2015). Both women were anti-apartheid activists with long histories of resistance and struggle. Since early 2013, they had held standing protests every Wednesday in front of Parliament against the new nuclear programme. There were also some ANC allies, such as the Congress of South African Trade Unions (COSATU) and the National Union of Mineworkers (NUM), who spoke out against the nuclear deal after President Zuma's SONA in 2014 (Mammburu, 2014). ${ }^{10}$

Investigative journalists from the Mail \& Guardian, amaBhungane, City Press, Business Day, and the Daily Maverick played a significant role in building public awareness around the nuclear deal and in enabling the launch of the Public Protector's investi-

10 In June 2014, it was unclear whether Zuma would review his nuclear ambitions after the government's alliance partners, COSATU and NUM, aired objections to the President's pronuclear SONA delivered on 17 June. COSATU aired its position on the matter in a statement (COSATU, 2014) and the NUM expressed itself very strongly after a special meeting of its National Executive Committee on 19 June 2014. 
gations (Public Protector, 2016). The journalists provided considerable insight into the nuclear deal processes, giving whistle-blowers in government institutions the opportunity to speak out about corruption from as early as 2011 . The media attention and public awareness became enabling factors that supported the work of civil society organisations on litigation and in protests. Finally, on 26 April 2017, the High Court ruled the nuclear deal unlawful and unconstitutional, based on the following findings:

- The intergovernmental agreement with Russia had been tabled by the Minister in Parliament as non-technical and non-binding instead of debating and seeking acceptance by Parliament of a binding agreement.

- Both Determinations 34 (signed in 2013 and 2016) were declared unlawful and unconstitutional because due process had not been followed.

- NERSA had not undertaken any public participation processes, as required by law and had failed to assess both Determinations 34 properly.

McDaid has noted that the application to the Western Cape High Court was not a random choice; it was selected as a court that would have the capacity to ensure an independent ruling (McDaid, 2019). For civil activists to succeed in a legal case, they need to have the necessary capacity. The anti-nuclear movement in South Africa appears to be well-established with a history of successful litigations on information disclosure and public participation.

\subsection{NUCLEAR DISCOURSE POST-ZUMA}

Cyril Ramaphosa became President in February 2018 and made changes to the Cabinet and the Boards of SOEs. Following the appointment of Jeff Radebe as the Minster of Energy, the draft IRP 2018 was tabled for comments on 27 August 2018, signed and eventually gazetted in October 2019 (Department of Mineral Resources and Energy, 2019).

The original draft of the IRP had not included procurement of nuclear energy, but several NGOs lobbied for the inclusion of nuclear energy. The National Society of Black Engineers of South Africa, the Black Business Council and the South African Energy Forum (SAEF) jointly submitted their "People's IRP” document to Parliament's Commission on Energy. This submission suggested that nuclear and coal energies should play a significant role in the South African energy mix to drive economic development (Black Business Council and South African Energy Forum, 2018). The document suggested an increase from the currently installed $1.8 \mathrm{GW}$ of nuclear power to $29 \mathrm{GW}$ of installed nuclear generation by 2050 . SAEF, an NGO that actively protects Zuma's interests and is not transparent regarding its funding and membership, set up a Twitter campaign and established dedicated WhatsApp groups to promote nuclear 
energy as a technology that would allow for transformation in South Africa and to position renewable energy as serving private Western interests (Kachur \& LeRoux, 2021). While nuclear energy can be a valid option for South Africa, the funding and representation of current lobbing organisations are secretive, creating suspicions about transparency and accountability of any future nuclear programme.

The long-awaited IRP 2019 was then gazetted, but it was an "older version" that stated that South Africa would "immediately commence the nuclear build programme to the extent of 2,5 GW because it is a no-regret option in the long term" (Omarjee \& Cronje, 2019; BusinessTech, 2019).

The revised, official document then changed to: "Commence preparations for a nuclear build programme to the extent of $2.5 \mathrm{GW}$ at a pace and scale that the country can afford because it is a no-regret option in the long term" (Department of Mineral Resources and Energy, 2019, p. 48).

\subsection{CONCLUSION}

South Africa needs a large-scale, evidence-based public dialogue about the country's energy mix to foster a common understanding and to develop a shared strategy. It is critical that the government's procurement process for energy, whether renewable or nuclear, is transparent and accountable. Not following transparent procurement processes will inevitably lead to significant developmental and financial losses, like those that occurred when the REIPPP programme was halted in 2015, while all the investments in the nuclear programme up until 2017 came to nought.

The nuclear energy deal has illustrated how legislation can be manipulated, institutions overpowered, and decision-making processes shaded from the public to serve personal and geopolitical interests. More specifically, NERSA has proven itself incapable of ensuring the independent regulation of energy processes. This needs to be addressed to ensure transparent and accountable energy procurement processes in the future.

The deal has also illustrated how a well-crafted legal framework and an active civil society can prevent those in executive power from taking unilateral and irrational decisions. A few of the factors that prevented the nuclear deal from being implemented were the bravery of whistle-blowers, the strength of the financial system, international regulatory systems, an active civil society and South Africa's Western Cape High Court.

The personal examples of public servants who openly spoke out against corruption like Nene, Gordhan, Jonas and many other whistle-blowers, play an important role in setting examples of good governance. The agency of the individual in defending the principals of democracy is essential. In this act, we are reminded that often it 
is singular people who take personal risks in the interests of good governance and transparency. The financial markets acted as a counterweight to individual political ambitions in its vehement reaction to the dismissal of Nene, triggering Nene-Gate. This negated the appointment of a new Minister of Finance more supportive of Zuma's ambitions who would most likely have approved the deal. The IAEA requirement for an intergovernmental agreement between South Africa and Russia for the purpose of building nuclear power stations provided an opportunity for civil society to submit their opposition to the courts and expose the dangers related to the proposed agreement. An active civil society was able to collect evidence and pursue the legal court case against the government without fear of reprisal from the state. And the Western Cape High Court was able to make an independent ruling and thus ensure a fair and transparent outcome. The independence of the judicial system is crucial for democracy to flourish.

Looking back at this protracted and desperate battle against power held by manipulative and largely self-serving hands, an important question needs to be asked: what needs to happen to prevent attempts of a corrupt nuclear deal in future? McDaid (2019) notes that, "We will keep going in loops unless we extract people from the department who were taking bribes and put them in jail". The Zondo Commission, which began its work on 21 August 2018 and was still hearing testimony at the time of writing, is an attempt to restore justice and heal the state from the rackets of corruption, but much will depend on its final report and the subsequent actions taken by state institutions. Individuals that have been removed from state institutions due to misconduct are already interviewing for reappointment, such as NECSA CEO Phumzile Tshelane (Yelland, 2020).

What is chillingly clear is that South Africa's failed nuclear energy deal, in which two Presidents tried to implement an ambitious project not aligned with this developing nation's energy demand and financial capabilities, remains a reality in another 18 countries on the African continent where discussions about building nuclear power stations by Rosatom continue.

In 2020, the DMRE issued a request for information to be able to assess nuclear technologies for the $2.5 \mathrm{GW}$ capacity stipulated in the 2019 IRP. The department explains this as a market testing exercise and is exploring the option of modular reactors. With job creation, social equality and a Covid-19 recovery economic pathway as priorities for South Africa, the exploration into any energy option, including nuclear, needs to comply with transparent and accountable governance processes and sound development practices. 


\section{References}

amaBhungane (2014) Another state bonanza for the Guptas', Daily Maverick. [Online]. https://bit.ly/3k533pV

Arkhangelskaya, A. \& Shubin, V. (2013) 'Russia's Africa Policy', Global Powers and Africa Programme. 157. Johannesburg. [Online]. https://saiia.org.za/research/russias-africapolicy/ (Accessed 19 July 2020).

Bezuidenhout, J. (2019) The impact of Nenegate: No, You can't simply pick up a plunging rand, Daily Maverick. Cape Town. [Online]. https://bit.ly/3CJoZ24

Bhorat, H., Buthelezi, M., Chipkin, I., Duma, S., Mondi, L., Peter, C., Qobo, M. \& Swilling, M. (2017) Betrayal of the Promise: How South Africa is being stolen, State Capacity Research Project. South Africa. [Online]. https://bit.ly/ $3 x \mathrm{GPhhC}$

Black Business Council and South African Energy Forum (2018) 'The People's IRP 2018-2050 - Presentation at Hearing On The Draft Integrated Resource Plan 2018 (IRP) [26 October 2018]', Parliamentary Monitoring Group (PMG). Cape Town. [Online].https://bit.ly/3sicllV

Burke, J. (2019) 'Russia pushing 'unsuitable' nuclear power in Africa, critics claim', The Guardian. [Online]. https://bit.ly/3xD8KQp

Centre for Environmental Rights (2017) Recent engagements between Minister of Energy and civil society organisations. [Online]. https:// bit.ly/3xJpw0e

Chernobyl Forum (2006) Chernobyl's legacy: Health, Environmental and Socio-Economic Impacts and Recommendations to the Governments of Belarus, the Russian Federation and Ukraine. 2nd Revised Version. Vienna: International Atomic Energy Agency (IAEA). https://bit.ly/37Bi38V

Cilliers, C. (2016) 'Is Zuma Putin the knife into SA?', The Citizen. [Online]. https://bit.ly/ 3AGstRj (Accessed 17 July 2020).

COSATU (2014) 'Statement by the Congress of South African Trade Unions [COSATU], on President Jacob Zuma's State of the Nation Address delivered on 17 June 2014
(19/06/2014)', Polity.org. https://bit.ly/ 3jMC0iW (Accessed 17 July 2020).

Death, C. (2006) 'Resisting (Nuclear) Power? Environmental Regulation in South Africa, Review of African Political Economy, 33(109):407-424. https://doi. org/10.1080/03056240601000788

De Lange, J. (2018) 'State was willing to lie to SA over costs of Zuma's nuclear plan', City Press. [Online]. https://bit.ly/3AEXODF (Accessed 17 July 2020).

Department of Energy (2011) Integrated Resource Plan (IRP) for Electricity 2010-2030. Pretoria. [Online]. https://bit. ly/37CU9di (Accessed 17 July 2020).

Department of Energy (2013) Integrated Resource Plan for Electricity (IRP) 2010-2030: Update Report 2013. Pretoria. [Online]. https://bit.ly/3jHk4pC (Accessed 17 July 2020).

Department of Energy (2014) Media Release Russia and South Africa sign agreement on Strategic Partnership in Nuclear Energy [22 September 2014]. [Online]. https://bit. ly/3fZ1SHf

Department of Energy (2015a) 'Determination Under Section 34(1) of the Electricity Regulation Act 4 [2006]: Nuclear Programme', Government Gazette. Pretoria. [Online]. https://bit.ly/3fZ1wQN

Department of Energy (2015b) 'Portfolio Committee on Energy: Report of the Nuclear New Build Procurement Programme of Sixteen (16) Service Providers [29 November 2015]', Parliamentary Monitoring Group (PMG). [Online]. https://bit.ly/3yG6k4N (Accessed 17 July 2020).

Department of Energy (2016a) 'Determination Under Section 34(1) of the Electricity Regulation Act 4 [2006]: Nuclear Programme Ammendment', Government Gazette. [Online]. https://bit.ly/3iHuPcy (Accessed 17 July 2020).

Department of Energy (2016b) Integrated Resource Plan Update: Assumptions, Base Case Results and Observations [November 
2016], Department of Energy. Pretoria.

[Online]. https://bit.ly/3m4Q89I

Department of Mineral Resources and Energy (2019) 'Integrated Resource Plan [2019], Department of Mineral Resources and Energy. Pretoria.

Department of Minerals and Energy (2008) Nuclear Energy Policy for the Rebublic of South Africa, Department of Minerals and Energy. Pretoria. [Online]. https://bit. ly/2VQDAYs

Department of Public Enterprises (2008) 'Media briefing by DG of Public Enterprises on Procurement of nuclear energy capacity (transcript)', Government Communication and Information System (GCIS). [Online]. https://bit.ly/3iGPOME (Accessed 28 October 2020).

Eberhard, A. \& Godinho, C. (2017) 'Eskom Inquiry Reference Book', State Capacity Research Project. University of Cape Town's Graduate School of Business \& State Capacity Research Project (SCRP). Cape Town. [Online]. https://bit.ly/3gg2JDF

Eberhard, A. \& Naude, R. (2017) 'South African Renewable Energy IPP Procurement Programme: Review, Lessons Learned \& Proposals to Reduce Transaction Costs', University of Cape Town Graduate School of Business. Cape Town. [Online]. https:// bit.ly/2VNGVHM

Eskom (2007) 'Eskom Annual Report 2007', Eskom Holdings Ltd. Johannesburg. [Online]. https://bit.ly/2XgMsr7

Eskom (2009) 'Eskom Annual Report 2009: Empowering the South African dream', Eskom Holdings Ltd. Johannesburg. [Online]. https://bit.ly/3ACutKd

Eskom (2014) Fitch Ratings revises the ratings outlook of Eskom Holdings SOC Limited to Negative from Stable. [Online]. https://bit.ly/3xGeUPG

Fig, D. (2006) 'Political Fission: South Africa's Nuclear Programme', Energy \& Environment, 17(3). https://doi. org/10.1260/095830506778119470

Fig, D. (2010) Nuclear energy rethink? The rise and demise of South Africas Pebble Bed
Modular Reactor, Institute of Security Studies (ISS) Africa. 210. Pretoria: Institute for Security Studies (ISS). [Online]. https://bit. ly/2VRPwtm (Accessed 30 October 2020).

Filatova, I.I. \& Davidson, A.B. (2013) The Hidden Thread: Russia and South Africa in the Soviet Era. Johannesburg: Jonathan Ball.

Fin24 \& City Press (2014) Nuclear deal team effort-presidency. [Online]. https://bit.ly/ 2VHF9IU.

Flak, A. (2011) 'Peters signs off on nuclear plan', IOL. [Online]. https://bit.ly/3IXJBxO (Accessed 19 July 2020).

Forensics for Justice (2018) Sworn Statementname redacted [allegations of abuses in State Security opperations. Johannesburg. [Online]. https://bit.ly/2XduE02

Fuzile, L. (2018) 'Statement and Documents Submitted by Lungisa Fuzile', Commission of Inquiry into State Capture. Johannesburg.

Gil, L. (2018) 'Is Africa Ready for Nuclear Energy?', International Atomic Energy Agency (IAEA). [Online]. https://bitly/ 3ABBiMe (Accessed 17 July 2020).

Gonchar, M., Chubyk, A., Dyachenko, S., Ishchuk, O., Lakiichuk, P., Hychka, O. \& Mukhrynsky, S. (2017) Wars - XXI: Russia's Polyhybression. Kyiv: Avega publ. house.

Gordhan, P. (2018) 'Statement and Documents Submitted by Pravin Gordhan', Commission of Inquiry into State Capture. Johannesburg.

Gosam, L. (2017) 'Lily Gosam: Zuma, the Guptas and the Russians - the inside story', Rand Daily Mail. [Online]. https://bit.ly/37z9MSY (Accessed 19 July 2020).

Hairsine, K. (2020) 'Russia's nuclear play for power in Africa', Deutsche Welle (DW). [Online].https://bit.ly/3AAJeNB

Hunter, Q. (2014) 'Jacob Zuma’s secret nuke "stitch-up", Mail \& Guardian. [Online]. https://bit.ly/3yKFwjZ

IAEA (2011) 'Basic Principles Objectives IAEA Nuclear Energy Series Stakeholder Involvement Throughout the Life Cycle of Nuclear Facilities', IAEA Nuclear Energy Series. No. NG-T-1.4. Vienna. [Online]. https://bit.ly/2UcFBOX 
International Atomic Energy Agency (IAEA) (2013) Mission Report on the Integrated Nuclear Infrastructure Review (INIR). [Online].https://bit.ly/3xG66tg (Accessed 29 October 2020).

Joubert, J.J. (2017) 'Exclusive: Energy minister investigates R80m in irregularities in nuclear contract', Times Live. [Online]. https://bit.ly/ 3yFKHBS

Joubert, J.J. \& Magubane, K. (2017) 'Mahlobo announces energy indaba for public participation on nuclear programme', Business Day. [Online]. https://bitly/37yugLI (Accessed 23 October 2020).

Kachur, D. \& LeRoux, J. (2021) 'Social Media, Russia's Energy Agenda, and the case of the South African Energy Forum, The Centre for Complex Systems in Transitions. Stellenbosch.

Kantey, M. (2017) Nukes? No Thanks! Five Arguments against Nuclear Power in South Africa. Plettenberg Bay: Watermark Press.

Kremlin (2010) 'Joint news conference with President of South Africa Jacob Zuma [5 August 2010]', President of Russia. [Online]. https://bit.ly/3ADolkQ

Kulyaev, A. (2017) 'Embassy's Comment on the Article «How Putin had a hand in Cabinet reshuffle» (Sunday Times)', Embassy of the Russian Federation in the Republic of South Africa, Press Release. [Online]. https://bitly/ 3iFfysv

Levington, M., Van Dyk, J., Eberhard, A. \& Bischof-Niemz, T. (2016) 'Comments on the Integrated Resource Plan 2016 Draft South African Integrated Resource Plan 2016 public hearing, Ministerial Advisory Council on Energy (MACE). Johannesburg. [Online]. https://bit.ly/3jN9JbN (Accessed 17 July 2020).

Locatelli, G. (2018) ‘Why are Megaprojects, Including Nuclear Power Plants, Delivered Overbudget and Late? Reasons and Remedies', Report MIT-ANP-TR-172, Center for Advanced Nuclear Energy Systems (CANES), Massachusetts Institute of Technology. [Online]. https://bit.ly/ 31TCwON (Accessed 28 October 2020).
Mahlobo, D. (2017) 'Closing Remarks for the Energy Indaba the Minister of Energy, Hon Mr David Mahlobo, MP, at the Gallagher Estate, Midrand, Johannesburg on the 08th December 2017', Department of Energy. [Online]. https://bit.ly/3yFLX84 (Accessed 28 October 2020).

Mammburu, L. (2014) Arrest and prosecute those involved in platinum sector strike violence, Politicsweb. [Online]. https:// bit.ly/2UftoZo (Accessed 19 July 2020).

Martin, B. \& Fig, D. (2015) 'Final Report-Findings of the African Nuclear Study', Heinrich-BöllStiftung. Cape Town. [Online]. https://bit. ly/3yJGrRH (Accessed 19 July 2020).

Martins, D.B. (2013) 'Minister of Energy, Dikobe Ben Martins: Remarks at the announcement of the outcome of the Window 3 Renewable Energy Independent Power Producer Procurement Programme (REIPPP)', South African Government. [Online]. https://bit.ly/3f V3em4

Maughan, K. (2019) 'Load-shedding would be history if SA had signed Russian deal, says Jacob Zuma', Business Day. [Online]. https:// bit.ly $/ 31 X 8 \mathrm{cmr}$

Mbatha, A. \& Crowley, K. (2014) 'South Africa Must Find \$23 Billion to Foil Eskom Junk Rating, Bloomberg. Johannesburg. [Online]. https://bloom.bg/3Awrl2q

McDaid, L. (2019) Interview with Liz McDaid by D. Kachur and N. Callaghan. Cape Town.

Mkokeli, S. \& Marrian, N. (2015) 'Interview with former president Kgalema Motlanthe', Business Day. [Online]. https://bit.ly/ 2VOgtle

Montmasson-Clair, G. \& Ryan, G. (2014) 'Repositioning electricity planning at the core: An evaluation of South Africa's Integrated Resource Plan', Trade and Industrial Policy Secretariat (TIPS). Pretoria. [Online]. https://bit.ly/37Cqd12 (Accessed 19 July 2020). https://doi.org/10.2139/ ssrn. 2747875

Nakano, J. (2020) 'The Changing Geopolitics of Nuclear Energy. A Look at the United States, Russia, and China, Center for Strategic and International Studies (CSIS). Washington. https://bit.ly/2Vligoa 
National Planning Commission (2012) National Development Plan 2030: Our Future-make it work. Pretoria: Department of the Presidency Republic of South Africa.

Nene, N. 2018. 'Statement and Documents Submitted by Nhlanhla Nene', Commission of Inquiry into State Capture. Johannesburg.

Omarjee, L. \& Cronje, J. (2019) 'Government gazetted wrong version of master energy plan - report', Fin24. [Online]. https://bit.ly/ 3CJArL6 (Accessed 3 November 2020).

Pehuet Lucet, F. (2018) 'Conditions and possibilities for financing new nuclear power plants', The Journal of World Energy Law \& Business, 12(1):21-35. https://doi. org/10.1093/jwelb/jwy032

PMG (Parliamentary Monitoring Group) (2016) Portfolio Committee on Energy: Nuclear New Build: briefing by Minister and Department of Energy [11 October 2016]. [Online]. https://bit.ly/3ABHwM6

PMG (Parliamentary Monitoring Group) (2018) Portfolio Committee on Energy: Minister of Energy Mahlobo on Department Performance [20 February 2018]. [Online]. https://bit.ly/3xHCbRx

Press-service of JSC Rusatom Overseas (2012) 'Rosatom marketing office registered in South Africa', AtomInfo RU. [Online]. https://bit. ly $/ 3 \mathrm{j} \mathrm{Nr} 3 \mathrm{~h} 0$

Prins, N. (2018) 'South Africa's nuclear new-build programme: The domestic requirements for nuclear energy procurement and public finance implications', WWF South Africa. Cape Town. [Online]. https://bit.ly/ 2VOIl5o (Accessed 17 July 2020).

Public Protector (2016) State of Capture. [Online]. https://bit.ly/3iHWt9j (Accessed 1 September 2018).

Putin, V. (2013) 'Press statements following talks with President of South Africa Jacob Zuma', President of Russia. Russia. [Online]. https:// bit.ly/2VN6wke

Rennkamp, B. \& Bhuyan, R. (2016) 'The social shaping of nuclear energy technology in South Africa', WIDER Working Paper 2016/19. Helsinki: The United Nations University World Institute for Development
Economics Research (UNU-WIDER). [Online]. https://doi.org/10.35188/UNUWIDER/2016/062-1

Republic of South Africa (2006) 'Electricity Regulation Act No. 4 [2006]', Government Gazette. Pretoria.

Republic of South Africa and Russian Federation (2014) Agreement between the Government of the Republic of South Africa and the Government of the Russian Federation on Strategic Partnership and Cooperation in the Fields of Nuclear Power and Industry', Department of International Relations and Cooperation (DIRCO). Vienna. [Online]. https://bit.ly/37R6g6N (Accessed 24 October 2020).

Rossiyskaya Gazeta (2012) 'Rosatom's foreign orders portfolio reaches $\$ 50$ billion [Interview with Kiril Komarov, Deputy CEO on international business development]', zato26.org. [Online]. https://bit.ly/3ABKJv8

South African Council of Churches (SACC) (2017) SACC Report to the Church Public on the Unburdening Panel Process Regina Mundi Church, Soweto [18 May 2017]. [Online]. https://bit.ly/2XnPOZC (Accessed 19 July 2020).

Shubin, V.G. (2008) ANC: a view from Moscow. Second. Auckland Park, South Africa: Jacana Media.

Sidimba, L. (2020) 'Mystery creditor demands R3bn from Gupta firm, Shiva Uranium', $I O L$. [Online]. https://bit.ly/3jREWdU

Slivyak, V. (2019) 'Dreams and reality of the Russian reactor export', Ecodefence. [Online]. https://bit.ly/3yGZ60H

Staff Reporter (2015) 'Nuclear price tag set Nene against Jacob Zuma', Mail \& Guardian. [Online]. https://bit.ly/2U9BaUs

BusinessTech (2019) 'Government published the wrong energy plan - here's the correct version. [Online]. https://bit.ly/3s8WKFk (Accessed 3 November 2020).

Tanter, R. (2013) 'After Fukushima: A Survey of Corruption in the Global Nuclear Power Industry,', Asian Perspective, 37(4):475-500. https://doi.org/10.1353/apr.2013.0020 
TASS (2014) 'Kiriyenko: Rosatom will supply eight nuclear power units to South Africa by 2023', TASS: Economy and Business. [Online]. https://bit.ly/3CAbphs

The Presidency (2015a) Announcement of New Ministers of Finance and COGTA', Media Statement. [Online]. https://bit.ly/3yBSyQN

The Presidency (2015b) 'President Jacob Zuma: Reply to parliamentary questions [27 March 2015]', South African Government. Cape Town. [Online]. https://bit.ly/3iGmQfH

Van Onselen, G. (2017) 'Political Musical Chairs: Turnover in the National Executive and Administration Since 2009', South African Institute of Race Relations. Johannesburg.

Wa Afrika, M., Jika, T. \& Skiti, S. (2017) 'From Russia with love: How Putin had a hand in Cabinet reshuffle', Sunday Times. [Online]. https://bit.ly/3iE5f84 (Accessed 19 July 2020).

Wealer, B., Bauer, S., Göke, L., Von Hirschhausen, C.R. \& Kemfert, C. (2019) 'High-priced and dangerous: Nuclear power is not an option for the climate-friendly energy mix', DIW Weekly Report, 9(30):235-243. Berlin: Deutsches Institut für Wirtschaftsforschung (DIW).

Western Cape High Court (2005) Earthlife Africa (Cape Town) v Director General Department of Environmental Affairs and Tourism and Another (7653/03) [2005]. [Online]. https://bit.ly/3m1VId5

Western Cape High Court (2015) Earthlife Africa Johannesburg and Another v Minister of Energy and Others (19529/2015) [2017]. [Online].https://bit.ly/3xE4foD

Wright, J.G., Bischof-Niemz, T., Calitz, J., Mushwana, C., Van Heerden, R. \& Senatla, M. (2017) 'Formal comments on the Integrated Resource Plan (IRP) Update Assumptions,
Base Case and Observations 2016,' Council for Scientific and Industrial Research (CSIR). Pretoria. [Online]. https://bit.ly/3AAm3TF (Accessed 19 July 2020).

Yelland, C. (2017) 'Irrational IRP madness grips SA's energy sector', Fin24. [Online]. https:// bit.ly/3CAcMN8 (Accessed 23 October 2020).

Yelland, C. (2020) 'Fired former nuclear CEO runs for office again', EE Business Intelligence. [Online]. https://bit.ly/3yBU8Cd

Yelland, C. \& Potgieter, P. (2017) 'Interview: Eskom's chief nuclear officer on renewed interest in the Pebble Bed Modular Reactor', Daily Maverick. [Online]. https://bit.ly/ 37CkDvs

Zondo Commission (2018a) 'Transcript from Inquiry into State Capture: Day 003 (24-08-2018) - Testimony of Mcebisi Jonas', Commission of Inquiry into State Capture. Johannesburg.

Zondo Commission (2018b) 'Transcript from Inquiry into State Capture: Day 019 (03-10-2018) - Testimony of Nhlanhla Nene', Commission of Inquiry into State Capture. [Online]. https://bit.ly/3AGnbVZ

Zondo Commission (2018c) 'Transcript from Inquiry into State Capture: Day 028 (22-11-2018) - Testimony of Lungisa Fuzile', Commission of Inquiry into State Capture. [Online].https://bit.ly/37zxEFV

Zuma, J.G. (2014) 'President Jacob Zuma: State of the Nation Address [February] 2014', South African Government. [Online]. https://bit.ly/ 3jRZUJA (Accessed 19 July 2020).

Zuma, J.G. (2015) 'President Jacob Zuma: State of the Nation Address [February] 2015', South African Government. [Online]. https://bit.ly/ 3iEMWQc (Accessed 19 July 2020). 



\section{APPENDIX}

\begin{tabular}{|c|c|c|c|c|}
\hline $\begin{array}{l}\text { Case Study } \\
\text { in State } \\
\text { Capture }\end{array}$ & Status & Summary Description & $\begin{array}{l}\text { Investigation } \\
\text { Body / } \\
\text { Source of } \\
\text { Evidence }\end{array}$ & $\begin{array}{l}\text { Government } \\
\text { Entity } \\
\text { Implicated }\end{array}$ \\
\hline \multicolumn{5}{|c|}{ Scandals Connected to Jacob Zuma, Guptas, Other Key Networks and ANC Politics } \\
\hline $\begin{array}{l}\text { The State } \\
\text { of Capture } \\
\text { report - } \\
\text { focuses } \\
\text { on Guptas' } \\
\text { relationship } \\
\text { with Jacob } \\
\text { Zuma and } \\
\text { their alleged } \\
\text { influence on } \\
\text { the affairs } \\
\text { of state }\end{array}$ & $\begin{array}{l}\text { First complaint } \\
\text { was received } \\
\text { in March } 2016 \\
\text { and the report } \\
\text { was released in } \\
\text { November } 2016 .\end{array}$ & $\begin{array}{l}\text { Investigation into complaints of alleged improper } \\
\text { and unethical conduct by the President and } \\
\text { other State Functionaries, relating to alleged } \\
\text { improper relationships and involvement of the } \\
\text { Gupta Family in the removal and appointment } \\
\text { of Ministers and Directors of State-Owned } \\
\text { Enterprises (SOEs), resulting in improper and } \\
\text { possibly corrupt award of State Contracts and } \\
\text { Benefits to the Gupta Family's Businesses. } \\
\text { The report details numerous allegations of } \\
\text { the Guptas' involvement in affairs of the state } \\
\text { and their irregular activities that enable rent } \\
\text { extraction. The findings were not conclusive } \\
\text { and the remedial action was to establish a } \\
\text { commission of inquiry into state capture (to } \\
\text { be appointed by the President, but with a } \\
\text { judge selected by the Chief Justice). Litigation } \\
\text { endeavoured to delay or prohibit the report's } \\
\text { release and implementation of remedial actions, } \\
\text { but failed, and the commission was established } \\
\text { in } 2018 \text {. }\end{array}$ & $\begin{array}{l}\text { - Public } \\
\text { Protector, } \\
\text { followed by } \\
\text { litigation }\end{array}$ & $\begin{array}{l}\text { - GCIS (The } \\
\text { New Age) } \\
\text { - Eskom } \\
\text { (Optimum) } \\
\text { - Transnet } \\
\text { (Regiments/ } \\
\text { Trillian) } \\
\text { - Denel } \\
\text { - SAA (The } \\
\text { New Age) } \\
\text { - SABC (The } \\
\text { New Age) } \\
\text { - Department of } \\
\text { Finance } \\
\text { - Transport } \\
\text { (SAA) } \\
\text { - Communica- } \\
\text { tions (SABC } \\
\text { \& GCIS) }\end{array}$ \\
\hline $\begin{array}{l}\text { Zondo } \\
\text { Commission }\end{array}$ & $\begin{array}{l}\text { Established } \\
\text { in 2018, with } \\
\text { anticipated } \\
\text { conclusion being } \\
\text { the end of } 2021 .\end{array}$ & $\begin{array}{l}\text { Formally titled the Judicial Commission of } \\
\text { Inquiry into Allegations of State Capture, } \\
\text { Corruption and Fraud in the Public Sector } \\
\text { including Organs of State, the Commission } \\
\text { was promulgated by then President Zuma in } \\
\text { response to the remedial actions as outlined in } \\
\text { the Public Protector's State of Capture report. } \\
\text { As of June } 2021 \text {, the Commission that started } \\
\text { in August } 2018 \text { has held more than } 418 \text { days } \\
\text { of hearings of over } 330 \text { testimonies (generating } \\
\text { over } 71000 \text { pages of transcript). The inquiry's } \\
\text { terms of reference were expansive and, as } \\
\text { such, the scope of investigations went beyond } \\
\text { merely looking into the Gupta-related cases, } \\
\text { covering other networks (e.g., Bosasa) as well } \\
\text { as other government institutions (e.g., role } \\
\text { of Parliament). }\end{array}$ & $\begin{array}{l}\text { - Zondo } \\
\text { Commission }\end{array}$ & $\begin{array}{l}\text { Various } \\
\text { work-streams } \\
\text { covering } \\
\text { inter alia: } \\
\text { - SOEs } \\
\text { (Eskom, } \\
\text { Transnet, } \\
\text { Denel, SAA) } \\
\text { - Free State } \\
\quad \text { Provincial } \\
\text { Government } \\
\text { - Bosasa } \\
\text { - SARS } \\
\text { - Law } \\
\text { enforcement } \\
\text { - State Security } \\
\text { Agency (SSA) } \\
\text { - The New Age } \\
\text { \& ANN7 } \\
\text { - Role of } \\
\text { Parliament } \\
\text { and ANC }\end{array}$ \\
\hline
\end{tabular}




\begin{tabular}{|c|c|c|c|c|}
\hline $\begin{array}{l}\text { Case Study } \\
\text { in State } \\
\text { Capture }\end{array}$ & Status & Summary Description & $\begin{array}{l}\text { Investigation } \\
\text { Body / } \\
\text { Source of } \\
\text { Evidence }\end{array}$ & $\begin{array}{l}\text { Government } \\
\text { Entity } \\
\text { Implicated }\end{array}$ \\
\hline \multicolumn{5}{|c|}{ Scandals Connected to Jacob Zuma, Guptas, Other Key Networks and ANC Politics } \\
\hline Bosasa & $\begin{array}{l}\text { Dating back to a } \\
2009 \text { SIU report. } \\
\text { Investigations and } \\
\text { various litigations } \\
\text { are ongoing. }\end{array}$ & $\begin{array}{l}\text { In 2019, former Bosasa C00, Anglo Agrizzi, } \\
\text { testified at the Zondo Commission, detailing } \\
\text { the acts and long history of corruption between } \\
\text { various Bosasa companies predominantly } \\
\text { owned by Gavin Watson, and numerous } \\
\text { government entities/departments. The } \\
\text { testimony of Agrizzi (and other former Bosasa } \\
\text { employees) corroborated the findings of a } \\
2009 \text { SIU investigation that alleged corruption } \\
\text { in several contracts Bosasa had with the } \\
\text { Department of Correctional Services. Criminal } \\
\text { court proceedings have been initiated based } \\
\text { on the } 2009 \text { SIU investigation, along with new } \\
\text { investigations initiated by SARS and other law } \\
\text { enforcement entities. }\end{array}$ & $\begin{array}{l}\text { - Special } \\
\text { Investi- } \\
\text { gation } \\
\text { Unit (SIU) } \\
\text { - Zondo } \\
\text { Commission }\end{array}$ & $\begin{array}{l}\text { - Department of } \\
\text { Correctional } \\
\text { Services } \\
\text { - Department of } \\
\text { Justice } \\
\text { - Department of } \\
\text { Home Affairs } \\
\text { - Department of } \\
\text { Transport } \\
\text { - Various SOEs } \\
\text { (e.g., SAPO, } \\
\text { ACSA) } \\
\text { - National } \\
\text { Prosecuting } \\
\text { Authority } \\
\text { (NPA) } \\
\text { - Members of } \\
\text { Parliament }\end{array}$ \\
\hline Arms Deal & $\begin{array}{l}\text { Various } \\
\text { investigations and } \\
\text { sources, dating } \\
\text { back to 1990s. } \\
\text { Most significant } \\
\text { source being } \\
\text { through Seriti } \\
\text { Commission. } \\
\text { Corruption case } \\
\text { against Zuma is } \\
\text { ongoing. }\end{array}$ & $\begin{array}{l}\text { Commission of Inquiry into allegations of fraud, } \\
\text { corruption, impropriety, or irregularity in the } \\
\text { Strategic Defence Procurement Packages } \\
\text { (SDPP). Various court cases related to } \\
\text { allegations of corruption against Jacob Zuma. } \\
\text { On Monday, } 24 \text { October 2011, the President } \\
\text { announced the Commission chaired by Judge } \\
\text { Seriti. The findings of the Commission were that } \\
\text { there was "no evidence" of corruption, but this } \\
\text { is seen by many to have been a whitewash. The } \\
\text { report was taken on review and set aside in } \\
\text { August 2019. The corruption case against Zuma } \\
\text { is ongoing before the courts. }\end{array}$ & $\begin{array}{l}\text { - Seriti } \\
\text { Commission } \\
\text { - Various } \\
\text { court cases }\end{array}$ & $\begin{array}{l}\text { Initially: } \\
\text { - South African } \\
\text { National } \\
\text { Defence } \\
\text { Force } \\
\text { - Members of } \\
\text { Parliament } \\
\text { Allegations also } \\
\text { involve: } \\
\text { - NPA } \\
\text { - SSA }\end{array}$ \\
\hline $\begin{array}{l}\text { Nkandla } \\
\text { Security } \\
\text { Upgrades }\end{array}$ & $\begin{array}{l}\text { Investigation } \\
\text { started in } \\
\text { November } 2012 . \\
\text { Report on } \\
\text { investigation } \\
\text { was released in } \\
\text { March } 2014 .\end{array}$ & $\begin{array}{l}\text { Report on security upgrades to President } \\
\text { Zuma's homestead in Nkandla. The investigation } \\
\text { found that the President unduly benefited from } \\
\text { the upgrades and as part of remedial actions } \\
\text { the President was required to pay back a portion } \\
\text { of the costs of the upgrades. Zuma instructed } \\
\text { that SAPS undertake their own investigation, } \\
\text { which sought to rationalise the expenses (fire- } \\
\text { pool report). Parliament accepted this alternative } \\
\text { report, but major court cases followed, } \\
\text { ultimately declaring that the Public Protector's } \\
\text { remedial actions are binding. President and } \\
\text { Parliament failed to uphold the Constitution. } \\
\text { President ordered to "pay back the money". }\end{array}$ & $\begin{array}{l}\text { - Public } \\
\text { Protector's } \\
\text { Secured } \\
\text { in Comfort } \\
\text { report, } \\
\text { followed by } \\
\text { litigation }\end{array}$ & $\begin{array}{l}\text { - Department of } \\
\text { Public Works } \\
\text { - South African } \\
\text { Police Service }\end{array}$ \\
\hline
\end{tabular}




\begin{tabular}{|c|c|c|c|c|}
\hline $\begin{array}{l}\text { Case Study } \\
\text { in State } \\
\text { Capture }\end{array}$ & Status & Summary Description & $\begin{array}{l}\text { Investigation } \\
\text { Body / } \\
\text { Source of } \\
\text { Evidence }\end{array}$ & $\begin{array}{l}\text { Government } \\
\text { Entity } \\
\text { Implicated }\end{array}$ \\
\hline \multicolumn{5}{|c|}{ Scandals Connected to Jacob Zuma, Guptas, Other Key Networks and ANC Politics } \\
\hline $\begin{array}{l}\text { Private } \\
\text { Aircraft } \\
\text { Landing at } \\
\text { Waterkloof } \\
\text { Airforce Base } \\
\text { and Gupta } \\
\text { Sun City } \\
\text { Wedding }\end{array}$ & May 2013. & $\begin{array}{l}\text { In 2013, justice, crime prevention, and } \\
\text { security cluster (JCPS) - a cabinet structure } \\
\text { composed of various ministries - undertook an } \\
\text { investigation into the Landing of a Commercial } \\
\text { aircraft at Air Force Base Waterkloof (report } \\
\text { titled the same). The investigation revealed that } \\
\text { the Guptas initially tried to organise a special } \\
\text { landing at OR Tambo International Airport, but } \\
\text { was turned down. They then approached the } \\
\text { Indian High Commission who re-designated the } \\
\text { wedding entourage as an official delegation to } \\
\text { secure a landing at the Waterkloof base. The } \\
\text { wedding held at Sun City was attended by a } \\
\text { number of high-profile ANC politicians and was } \\
\text { paid for in part by moneys looted from the Vrede } \\
\text { Dairy Farm project. }\end{array}$ & $\begin{array}{l}\text { - Report by } \\
\text { JPCS } \\
\text { - Zondo } \\
\text { Commission }\end{array}$ & $\begin{array}{l}\text { - Department of } \\
\text { International } \\
\text { Relations and } \\
\text { Cooperation } \\
\text { (DIRCO) } \\
\text { - Department of } \\
\text { Defence } \\
\text { - Department of } \\
\text { Transport }\end{array}$ \\
\hline $\begin{array}{l}\text { Free State } \\
\text { Provincial } \\
\text { Capture, } \\
\text { includes } \\
\text { Vrede Dairy } \\
\text { Farm and } \\
\text { Asbestos } \\
\text { Contracts }\end{array}$ & Ongoing. & $\begin{array}{l}\text { The Vrede Dairy Farm project was initiated } \\
\text { by the Free State Provincial Government as a } \\
\text { development project, however, in partnering with } \\
\text { a Gupta-linked company Estina, government } \\
\text { funds were looted. In 2018, the Public } \\
\text { Protector released a report on their } 2018 \\
\text { investigation, but it was taken on review and } \\
\text { set aside by the courts. The second part of the } \\
\text { investigation is yet to be finalised. The NPA } \\
\text { laid criminal charges against Gupta associates } \\
\text { and implicated government officials. Court } \\
\text { proceedings are ongoing. } \\
\text { Significant testimony and evidence have been } \\
\text { presented at the Zondo Commission regarding } \\
\text { the Vrede Farm case, as well as the asbestos } \\
\text { inspection project (criminal proceedings are also } \\
\text { underway). Both projects implicate high-profile } \\
\text { politicians and senior officials manipulating } \\
\text { government process. }\end{array}$ & $\begin{array}{l}\text { - } \text { Public } \\
\text { Protector } \\
\text { reports } \\
\text { - Zondo } \\
\text { Commission } \\
\text { - Various } \\
\text { court cases }\end{array}$ & $\begin{array}{l}\text { - Free State } \\
\text { Provincial } \\
\text { Government }\end{array}$ \\
\hline $\begin{array}{l}\text { Irregular } \\
\text { removal of } \\
\text { National } \\
\text { Director } \\
\text { of Public } \\
\text { Prosecutions } \\
\text { (NDPP), } \\
\text { Mxolisi } \\
\text { Nxasana }\end{array}$ & $\begin{array}{l}\text { Inquiry instituted } \\
\text { in February } 2015, \\
\text { but was cancelled } \\
\text { in May } 2015 . \\
\text { This triggers the } \\
\text { Constitutional Court } \\
\text { cases that followed. }\end{array}$ & $\begin{array}{l}\text { Inquiry into the fitness of Mxolisi Nxasana to } \\
\text { hold office as NDPP. The Inquiry was cancelled } \\
\text { after Zuma "agreed to let Nxasana resign". He } \\
\text { was paid R17m - the balance of his ten-year } \\
\text { contract. Court cases followed detailing the } \\
\text { abuse of the presidency powers by Zuma. } \\
\text { Ultimately, Nxasana was ordered to repay } \\
\text { R17m and Zuma's appointed replacement, } \\
\text { Shawn Abrahams, was ordered to vacate office. } \\
\text { Constitutional Court found Zuma's actions to } \\
\text { be an abuse of power and in breach of his } \\
\text { constitutional obligations. }\end{array}$ & $\begin{array}{l}\text { - Cassim } \\
\text { Inquiry into } \\
\text { fitness of } \\
\text { Mxolisi } \\
\text { Nxasana to } \\
\text { hold office } \\
\text { of NDPP } \\
\text { initiated } \\
\text { by Zuma, } \\
\text { followed by } \\
\text { litigation }\end{array}$ & $\begin{array}{l}\text { - National } \\
\text { Prosecution } \\
\text { Authority }\end{array}$ \\
\hline $\begin{array}{l}\text { Political } \\
\text { killings in } \\
\text { KZN }\end{array}$ & $\begin{array}{l}\text { Established in } \\
\text { October } 2016 . \text { The } \\
\text { report was released } \\
\text { in May } 2018 .\end{array}$ & $\begin{array}{l}\text { On } 28 \text { October 2016, the Premier of the } \\
\text { Province of KwaZulu-Natal established a } \\
\text { Commission of Enquiry into the Underlying } \\
\text { Causes of the Murder of Politicians in KwaZulu- } \\
\text { Natal (KZN). }\end{array}$ & $\begin{array}{l}\text { - Moerane } \\
\text { Commission } \\
\text { of Enquiry }\end{array}$ & $\begin{array}{l}\text { - KZN Provincial } \\
\text { Government } \\
\text { - KZN Local } \\
\text { Governments }\end{array}$ \\
\hline
\end{tabular}




\begin{tabular}{|c|c|c|c|c|}
\hline $\begin{array}{l}\text { Case Study } \\
\text { in State } \\
\text { Capture }\end{array}$ & Status & Summary Description & $\begin{array}{l}\text { Investigation } \\
\text { Body / } \\
\text { Source of } \\
\text { Evidence } \\
\end{array}$ & $\begin{array}{l}\text { Government } \\
\text { Entity } \\
\text { Implicated }\end{array}$ \\
\hline \multicolumn{5}{|c|}{ Scandals Connected to Jacob Zuma, Guptas, Other Key Networks and ANC Politics } \\
\hline \multicolumn{5}{|c|}{ State Capture of State-Owned Enterprises and Government Departments } \\
\hline $\begin{array}{l}\text { Interference } \\
\text { in operations } \\
\text { at the SABC }\end{array}$ & $\begin{array}{l}\text { The Ad Hoc } \\
\text { Committee was } \\
\text { established in } \\
\text { November } 2016 \\
\text { and final report } \\
\text { was tabled on } \\
24 \text { February } 2017 .\end{array}$ & $\begin{array}{l}\text { Parliamentary Ad Hoc Committee on the } \\
\text { SABC Board Inquiry into mismanagement and } \\
\text { interference in SABC operations. Findings } \\
\text { include evidence of Minister Faith Muthambi's } \\
\text { interference in the organisation and editorial } \\
\text { interference, in the firing of SABC } 8 \text { who } \\
\text { protested censorship of the national broadcaster } \\
\text { (on instruction from COO Hlaudi Motsoeneng). It } \\
\text { should be noted that the inquiry was preceded } \\
\text { by an investigation by the Public Protector. } \\
\text { Details are contained in the } 2014 \text { report titled } \\
\text { When Governance and Ethics Fail. }\end{array}$ & $\begin{array}{l}\text { - Parliamen- } \\
\text { tary Inquiry } \\
\text { - Preceded by } \\
\text { an investi- } \\
\text { gation by } \\
\text { the Public } \\
\text { Protector }\end{array}$ & $\begin{array}{l}\text { - SABC } \\
\text { (Department } \\
\text { of Communi- } \\
\text { cation) }\end{array}$ \\
\hline \multirow[t]{2}{*}{$\begin{array}{l}\text { Passenger } \\
\text { Rail Agency } \\
\text { of South } \\
\text { Africa } \\
\text { (PRASA) }\end{array}$} & $\begin{array}{l}\text { Complaints were } \\
\text { lodged in } 2012 \\
\text { and the report } \\
\text { was released in } \\
\text { August } 2015 .\end{array}$ & $\begin{array}{l}\text { Several cases of "mismanagement and } \\
\text { irregularities" regarding various contracts. } \\
\text { Lucky Montana was CEO at the time. One of } \\
\text { the remedial actions stipulated that National } \\
\text { Treasury was to investigate all PRASA contracts } \\
\text { from } 2012 \text { onwards with a value of R10 million } \\
\text { or more. National Treasury implemented the } \\
\text { remedial action which resulted in several } \\
\text { investigations, the details of which were leaked } \\
\text { to the public. }\end{array}$ & $\begin{array}{l}\text { - Public } \\
\text { Protector's } \\
\text { Derailed } \\
\text { report on } \\
\text { PRASA } \\
\text { - Numerous } \\
\text { investiga- } \\
\text { tions }\end{array}$ & $\begin{array}{l}\text { - PRASA } \\
\text { - Department of } \\
\text { Transport }\end{array}$ \\
\hline & $\begin{array}{l}\text { In June } 2017, \\
\text { Parliament directed } \\
4 \text { committees to } \\
\text { investigate state } \\
\text { capture. Committee } \\
\text { hearings were not } \\
\text { completed. }\end{array}$ & $\begin{array}{l}\text { In terms of the parliamentary directive, the } \\
\text { Portfolio Committee on Transport was requested } \\
\text { to establish an Inquiry into State Capture at } \\
\text { PRASA. However, the Portfolio Committee noted } \\
\text { that PRASA was not mentioned in the Public } \\
\text { Protector's State of Capture report and decided } \\
\text { they would focus on the various investigation } \\
\text { reports produced for National Treasury (as } \\
\text { recommended in Derailed report). }\end{array}$ & $\begin{array}{l}\text { - Portfolio } \\
\text { Committee } \\
\text { on Transport }\end{array}$ & $\begin{array}{l}\text { - PRASA } \\
\text { - Department of } \\
\text { Transport }\end{array}$ \\
\hline $\begin{array}{l}\text { Eskom } \\
\text { Inquiry into } \\
\text { State Capture }\end{array}$ & $\begin{array}{l}\text { In June } 2017 \text {, } \\
\text { Parliament directed } \\
4 \text { committees } \\
\text { to investigate } \\
\text { state capture. } \\
\text { Public Enterprises } \\
\text { Committee } \\
\text { report on Eskom } \\
\text { was released in } \\
\text { November } 2018 .\end{array}$ & $\begin{array}{l}\text { Extensive hearings were held by the Committee } \\
\text { detailing much of the evidence presented in } \\
\text { the Public Protector's report. The Committee } \\
\text { presented recommendations and compiled } \\
\text { a final report detailing their findings. These } \\
\text { included findings that Ministers Lynne Brown } \\
\text { and Malusi Gigaba were negligent and had to } \\
\text { be held accountable. Also recommended that } \\
\text { criminal investigations be undertaken against } \\
\text { the relevant Eskom executives. }\end{array}$ & $\begin{array}{l}\text { - Parliamen- } \\
\text { tary Inquiry }\end{array}$ & $\begin{array}{l}\text { - Eskom } \\
\text { - Department } \\
\text { of Public } \\
\text { Enterprises }\end{array}$ \\
\hline $\begin{array}{l}\text { Nugent } \\
\text { Commission } \\
\text { - SARS } \\
\text { Inquiry }\end{array}$ & $\begin{array}{l}\text { The Inquiry was } \\
\text { constituted on } \\
24 \text { May } 2018 \text { and } \\
\text { the final report } \\
\text { was released in } \\
\text { December } 2018 .\end{array}$ & $\begin{array}{l}\text { Commission of Inquiry into tax administration } \\
\text { and governance by South African Revenue } \\
\text { Service (SARS). Tom Moyane was fired based on } \\
\text { the interim report released in September } 2018 . \\
\text { The inquiry found that Moyane, with the help of } \\
\text { consultancy company Bain, had implemented } \\
\text { restructuring of the organisation, resulting in } \\
\text { gross mismanagement and erosion of SARS. } \\
\text { Moyane motivated the restructuring based on } \\
\text { the "rogue unit" narrative that has been the } \\
\text { subject of several other debunked investigations } \\
\text { and the subject of much litigation. }\end{array}$ & $\begin{array}{l}\text { - Judicial } \\
\text { Commission } \\
\text { of Inquiry } \\
\text { - Court cases } \\
\text { around the } \\
\text { "rogue unit" } \\
\text { narrative }\end{array}$ & $\begin{array}{l}\text { - SARS } \\
\text { (National } \\
\text { Treasury) }\end{array}$ \\
\hline
\end{tabular}




\begin{tabular}{|c|c|c|c|c|}
\hline $\begin{array}{l}\text { Case Study } \\
\text { in State } \\
\text { Capture }\end{array}$ & Status & Summary Description & $\begin{array}{l}\text { Investigation } \\
\text { Body / } \\
\text { Source of } \\
\text { Evidence }\end{array}$ & $\begin{array}{l}\text { Government } \\
\text { Entity } \\
\text { Implicated }\end{array}$ \\
\hline \multicolumn{5}{|c|}{ Scandals Connected to Jacob Zuma, Guptas, Other Key Networks and ANC Politics } \\
\hline \multicolumn{5}{|c|}{ State Capture of State-Owned Enterprises and Government Departments } \\
\hline $\begin{array}{l}\text { Commission } \\
\text { of Inquiry } \\
\text { into Public } \\
\text { Investment } \\
\text { Corporation } \\
\text { (PIC) }\end{array}$ & $\begin{array}{l}\text { In October } 2018 \text {, } \\
\text { the Commission } \\
\text { was constituted, } \\
\text { and the final report } \\
\text { was released in } \\
\text { March } 2020 .\end{array}$ & $\begin{array}{l}\text { Commission of Inquiry into allegations of } \\
\text { impropriety regarding Public Investment } \\
\text { Corporation (PIC). There were extensive hearings } \\
\text { on various 'dodgy' deals the PIC entered } \\
\text { into and details of political and executive } \\
\text { interference in the operations and decision- } \\
\text { making processes of the investment agency. }\end{array}$ & $\begin{array}{l}\text { - Judicial } \\
\text { Commission } \\
\text { of Inquiry }\end{array}$ & $\begin{array}{l}\text { - PIC (National } \\
\text { Treasury) }\end{array}$ \\
\hline $\begin{array}{l}\text { South African } \\
\text { Social } \\
\text { Security } \\
\text { Agency } \\
\text { (SASSA) }\end{array}$ & $\begin{array}{l}\text { Various } \\
\text { Constitutional Court } \\
\text { cases from } 2011 \\
\text { to } 2018 \text { resulted } \\
\text { in removal of CPS } \\
\text { as service provider } \\
\text { to SASSA. }\end{array}$ & $\begin{array}{l}\text { In 2014, South African Social Security Agency's } \\
\text { (SASSA) } 2012 \text { contract with CPS was found } \\
\text { to be irregular and invalid, however, due to the } \\
\text { importance of ensuring beneficiaries received } \\
\text { grants, CPS continued to be the service } \\
\text { providers until } 2018 \text {. Following a March } 2017 \\
\text { ruling, the Constitutional Court instituted a } \\
\text { Section } 38 \text { Inquiry into Minister Bathabile } \\
\text { Dlamini's personal liability for the narrowly } \\
\text { averted grant payment crisis. }\end{array}$ & $\begin{array}{l}\text { Primary } \\
\text { sources: } \\
\text { - AllPay court } \\
\text { case } \\
\text { - Black Sash } \\
\text { court case }\end{array}$ & - SASSA \\
\hline $\begin{array}{l}\text { South African } \\
\text { Airways (SAA) } \\
\text { and SAA } \\
\text { Technical }\end{array}$ & $\begin{array}{l}\text { Court case } \\
\text { to have Dudu } \\
\text { Myeni declared a } \\
\text { delinquent director } \\
\text { was launched } \\
\text { in } 2017 .\end{array}$ & $\begin{array}{l}\text { Court case was launched in } 2017 \text { by Outa and } \\
\text { the SAA Pilots' Association (SAAPA) to declare } \\
\text { Myeni a delinquent director in terms of the } \\
\text { Companies Act, based on her actions while she } \\
\text { was chairperson of the SAA Board. In 2020, the } \\
\text { High Court declared Myeni a delinquent director } \\
\text { for life. A significant amount of new evidence } \\
\text { also emerged through the Zondo Commission, } \\
\text { outlining how the operations at SAA were } \\
\text { undermined and how Myeni and others abused } \\
\text { their positions of authority. }\end{array}$ & $\begin{array}{l}\text { - Court } \\
\text { papers } \\
\text { - Zondo } \\
\text { Commission }\end{array}$ & $\begin{array}{l}\text { - SAA } \\
\text { - SAA Technical }\end{array}$ \\
\hline $\begin{array}{l}\text { Gupta Family } \\
\text { Naturalisation }\end{array}$ & $\begin{array}{l}\text { In June } 2017, \\
\text { Parliament directed } \\
4 \text { committees to } \\
\text { investigate state } \\
\text { capture. Final } \\
\text { report was tabled } \\
14 \text { March } 2019 .\end{array}$ & $\begin{array}{l}\text { Portfolio Committee on Home Affairs Inquiry into } \\
\text { the Gupta Family Naturalisation was established } \\
\text { in terms of the Parliamentary directive. Hearings } \\
\text { formally started on } 12 \text { September 2018. Final } \\
\text { report was tabled on } 14 \text { March 2019. Questions } \\
\text { were raised around contracts with Visa } \\
\text { Facilitation Services. This matter is ongoing as } \\
\text { of December } 2020 \text {. }\end{array}$ & $\begin{array}{l}\text { - Portfolio } \\
\text { Committee } \\
\text { on Home } \\
\text { Affairs }\end{array}$ & $\begin{array}{l}\text { - Department of } \\
\text { Home Affairs }\end{array}$ \\
\hline $\begin{array}{l}\text { Inquiry into } \\
\text { State Capture } \\
\text { related to } \\
\text { Gupta-owned } \\
\text { mines }\end{array}$ & $\begin{array}{l}\text { In June } 2017, \\
\text { Parliament directed } \\
4 \text { committees } \\
\text { to investigate } \\
\text { state capture. }\end{array}$ & $\begin{array}{l}\text { Though the Committee drafted a term of } \\
\text { reference for the Inquiry, the activities of holding } \\
\text { hearings and consolidating the evidence never } \\
\text { materialised beyond questions being put to then } \\
\text { Minister Zwane. }\end{array}$ & $\begin{array}{l}\text { - Portfolio } \\
\text { Committee } \\
\text { on Mineral } \\
\text { Resources }\end{array}$ & $\begin{array}{l}\text { - Department } \\
\text { of Mineral } \\
\text { Resources }\end{array}$ \\
\hline
\end{tabular}




\begin{tabular}{|c|c|c|c|c|}
\hline $\begin{array}{l}\text { Case Study } \\
\text { in State } \\
\text { Capture }\end{array}$ & Status & Summary Description & $\begin{array}{l}\text { Investigation } \\
\text { Body / } \\
\text { Source of } \\
\text { Evidence }\end{array}$ & $\begin{array}{l}\text { Government } \\
\text { Entity } \\
\text { Implicated }\end{array}$ \\
\hline \multicolumn{5}{|c|}{ Scandals Connected to Jacob Zuma, Guptas, Other Key Networks and ANC Politics } \\
\hline \multicolumn{5}{|c|}{ State Capture of State-Owned Enterprises and Government Departments } \\
\hline \multirow{3}{*}{$\begin{array}{l}\text { Various } \\
\text { investigations } \\
\text { relating to } \\
\text { State Capture } \\
\text { at Eskom }\end{array}$} & 2015 & $\begin{array}{l}\text { In } 2015 \text {, Dentons produced an interim report } \\
\text { on their investigations into Status of Business } \\
\text { and Challenges at Eskom. Their investigation } \\
\text { was halted. }\end{array}$ & - Eskom & - Eskom \\
\hline & \multirow[t]{2}{*}{2017} & $\begin{array}{l}\text { In 2017, PricewaterhouseCoopers (PwC) was } \\
\text { appointed by National Treasury to investigate } \\
\text { Eskom's Coal Procurement Processes. Damning } \\
\text { findings were made in relation to Gupta-owned } \\
\text { Tegeta mine contracts and poor coal quality. }\end{array}$ & - Eskom & - Eskom \\
\hline & & $\begin{array}{l}\text { G9 was contracted by Eskom to investigate } \\
\text { the Trillian/McKinsey contracts. Interim report } \\
\text { presented to Board of Eskom in August } 2017 . \\
\text { The investigation remained incomplete, and } \\
\text { no report is available in the public domain. } \\
\text { Evidence from the investigation was presented } \\
\text { in the Parliamentary Inquiry into Eskom } \\
\text { State Capture. }\end{array}$ & $\begin{array}{l}\text { - National } \\
\text { Treasury }\end{array}$ & - Eskom \\
\hline $\begin{array}{l}\text { National } \\
\text { Treasury } \\
\text { Fundudzi } \\
\text { reports, } \\
\text { related to } \\
\text { Eskom and } \\
\text { Transnet (x3) }\end{array}$ & $\begin{array}{l}\text { Final reports } \\
\text { compiled in } \\
\text { November } 2018 \\
\text { and released to } \\
\text { the public shortly } \\
\text { thereafter. }\end{array}$ & $\begin{array}{l}\text { Investigations requested by National Treasury } \\
\text { of alleged corruption at Transnet and Eskom. } \\
\text { The three reports focused on Eskom (general), } \\
\text { the contracts related to Trillian/McKinsey and } \\
\text { Transnet Locomotives. }\end{array}$ & $\begin{array}{l}\text { - National } \\
\text { Treasury } \\
\text { Fundudzi }\end{array}$ & $\begin{array}{l}\text { - Eskom } \\
\text { - Transnet }\end{array}$ \\
\hline \multirow[t]{2}{*}{$\begin{array}{l}\text { Transnet } \\
\text { Locomotive } \\
\text { Contracts }\end{array}$} & \multirow[t]{2}{*}{$\begin{array}{l}\text { Investigations } \\
\text { commenced in } \\
\text { December } 2017 \\
\text { and reports on } \\
\text { findings submitted } \\
\text { during } 2018 .\end{array}$} & $\begin{array}{l}\text { Werksmans Attorneys was appointed in } \\
\text { December } 2017 \text { to undertake an investigation } \\
\text { into the } 1064 \text { Transnet Locomotives } \\
\text { procurement process, however, the investigation } \\
\text { was halted. No report in the public domain. }\end{array}$ & - Werksmans & - Transnet \\
\hline & & $\begin{array}{l}\text { Mncedisi Ndlovu \& Sedumedi (MNS) Attorneys } \\
\text { was then appointed to investigate } 1064 \\
\text { locomotives procurement process. The report } \\
\text { is not in the public domain, but media indicates } \\
\text { that recommendations mirror the Werksmans' } \\
\text { findings and recommends that Molefe face } \\
\text { criminal charges. }\end{array}$ & $\begin{array}{l}\text { - Mncedisi } \\
\text { Ndlovu \& } \\
\text { Sedumedi }\end{array}$ & - Transnet \\
\hline $\begin{array}{l}\text { Inquiry into } \\
\text { State Capture } \\
\text { at Transnet } \\
\text { and Denel }\end{array}$ & \begin{tabular}{l|} 
In June 2017, \\
Parliament directed \\
4 committees to \\
investigate state \\
capture. Committee \\
hearings were not \\
completed.
\end{tabular} & $\begin{array}{l}\text { A detailed information booklet was prepared } \\
\text { in relation to Transnet, however, hearings were } \\
\text { not held before the end of term of Parliament. } \\
\text { Following National elections in 2019, it } \\
\text { was decided that outstanding Inquiries into } \\
\text { state capture be postponed indefinitely until } \\
\text { conclusion of the Zondo Commission. }\end{array}$ & $\begin{array}{l}\text { - Portfolio } \\
\text { Committee } \\
\text { on Public } \\
\text { Enterprises }\end{array}$ & $\begin{array}{l}\text { - Transnet } \\
\text { - Denel }\end{array}$ \\
\hline
\end{tabular}




\begin{tabular}{|c|c|c|c|c|}
\hline $\begin{array}{l}\text { Case Study } \\
\text { in State } \\
\text { Capture }\end{array}$ & Status & Summary Description & $\begin{array}{l}\text { Investigation } \\
\text { Body / } \\
\text { Source of } \\
\text { Evidence }\end{array}$ & $\begin{array}{l}\text { Government } \\
\text { Entity } \\
\text { Implicated }\end{array}$ \\
\hline \multicolumn{5}{|c|}{ Scandals Connected to Jacob Zuma, Guptas, Other Key Networks and ANC Politics } \\
\hline \multicolumn{5}{|c|}{ Law Enforcement and the Security Cluster } \\
\hline $\begin{array}{l}\text { Enquiry into } \\
\text { Jiba and } \\
\text { Mrwebi's } \\
\text { fitness to } \\
\text { hold office } \\
\text { at NPA }\end{array}$ & $\begin{array}{l}\text { Established in } \\
\text { November } 2018 . \\
\text { Report was issued } \\
\text { in April } 2019 .\end{array}$ & $\begin{array}{l}\text { Presidential Enquiry into the fitness to hold } \\
\text { office of suspended NPA senior advocates } \\
\text { Nomgcobo Jiba and Lawrence Mrwebi. NPA's } \\
\text { deputy head Jiba, and Mrwebi, the head of } \\
\text { the Specialised Commercial Crimes Unit, were } \\
\text { suspended in October } 2018 \text { by President Cyril } \\
\text { Ramaphosa. The Inquiry was headed by retired } \\
\text { Constitutional Court Justice Yvonne Mokgoro. } \\
\text { Jiba and Mrwebi were accused of improper } \\
\text { conduct in their handling of cases involving } \\
\text { former crime intelligence head Richard Mdluli, } \\
\text { as well as former KwaZulu-Natal Hawks boss } \\
\text { Johan Booysen. }\end{array}$ & $\begin{array}{c}\text { - Mokgoro } \\
\text { Enquiry }\end{array}$ & $\begin{array}{l}\text { - } \text { National } \\
\text { Prosecuting } \\
\text { Authority }\end{array}$ \\
\hline $\begin{array}{l}\text { High-Level } \\
\text { Review Panel } \\
\text { on the State } \\
\text { Security } \\
\text { Agency (SSA) }\end{array}$ & $\begin{array}{l}\text { Established in June } \\
2018 \text { and final } \\
\text { report was sent to } \\
\text { the President in } \\
\text { December } 2018 .\end{array}$ & $\begin{array}{l}\text { The High-Level Review Panel into the SSA } \\
\text { was established by President Ramaphosa in } \\
\text { June 2018. The key finding was a serious } \\
\text { politicisation and factionalisation of the } \\
\text { intelligence community over the past decade } \\
\text { or more. This resulted in "an almost complete } \\
\text { disregard for the Constitution, policy, legislation } \\
\text { and other prescripts, and [turned] our civilian } \\
\text { intelligence community into a private resource } \\
\text { to serve the political and personal interests of } \\
\text { particular individuals" (High-Level Review Panel } \\
\text { on the SSA, 2018, p.ii). }\end{array}$ & $\begin{array}{l}\text { - Review } \\
\text { Panel } \\
\text { established } \\
\text { by President } \\
\text { Ramaphosa }\end{array}$ & - SSA \\
\hline $\begin{array}{l}\text { Various court } \\
\text { cases against } \\
\text { persons } \\
\text { within law } \\
\text { enforcement }\end{array}$ & Ongoing. & $\begin{array}{l}\text { Though testimony and evidence have been } \\
\text { presented at the Zondo Commission, it is } \\
\text { understood that no definitive findings will be } \\
\text { made regarding the capture of law enforcement } \\
\text { under the Zuma administration. Since } 2012 \\
\text { onwards, there were several court cases } \\
\text { that were pursued against individuals in law } \\
\text { enforcement, all of which have been either } \\
\text { dismissed or withdrawn. Most noteworthy are } \\
\text { the cases involved, amongst others: Anwa } \\
\text { Dramat and Shadrack Sibiya of the Hawks } \\
\text { (and Robert McBride from Independent Police } \\
\text { Investigative Directorate [IPID]) for allegations } \\
\text { related to the "Zimbabwean rendition" matter; } \\
\text { Johan Booysen for alleged racketeering as part } \\
\text { of "Cato Manor hit squad"; and the various } \\
\text { senior officials accused of being part of the } \\
\text { "rogue" intelligence unit at SARS. Other court } \\
\text { cases that have provided significant evidence } \\
\text { indicating the capture of law enforcement relate } \\
\text { to the irregular appointed allies of the Shadow } \\
\text { State capture network or the irrational removal } \\
\text { of potential opponents holding senior positions } \\
\text { in law enforcement. Example is the irregular } \\
\text { removal of Mxolisi Nxasana as National Director } \\
\text { of Public Prosecutions (NDPP). }\end{array}$ & $\begin{array}{l}\text { - Various } \\
\text { court cases, } \\
\text { proceedings } \\
\text { in Parlia- } \\
\text { ment } \\
\text { - Zondo } \\
\text { Commission }\end{array}$ & $\begin{array}{l}\text { - NPA } \\
\text { - SAPS } \\
\text { - Hawks } \\
\text { - IPID }\end{array}$ \\
\hline
\end{tabular}




\begin{tabular}{|c|c|c|c|c|}
\hline $\begin{array}{l}\text { Case Study } \\
\text { in State } \\
\text { Capture }\end{array}$ & Status & Summary Description & $\begin{array}{l}\text { Investigation } \\
\text { Body / } \\
\text { Source of } \\
\text { Evidence }\end{array}$ & $\begin{array}{l}\text { Government } \\
\text { Entity } \\
\text { Implicated }\end{array}$ \\
\hline \multicolumn{5}{|c|}{ Scandals Connected to Jacob Zuma, Guptas, Other Key Networks and ANC Politics } \\
\hline \multicolumn{5}{|c|}{ Investigations concerning Private Sector } \\
\hline $\begin{array}{l}\text { Budlender } \\
\text { report on } \\
\text { Trillian }\end{array}$ & $\begin{array}{l}\text { Released in } \\
\text { June } 2017 .\end{array}$ & $\begin{array}{l}\text { Trillian Holdings Board appointed Geoff } \\
\text { Budlender SC to undertake investigations into } \\
\text { State Capture allegations at Trillian Capital. } \\
\text { Detailed accounts from whistle-blowers } \\
\text { highlighted how information was withheld by } \\
\text { senior management at Trillian. }\end{array}$ & - Trillion & - Eskom \\
\hline $\begin{array}{l}\text { Collapse of } \\
\text { VBS Mutual } \\
\text { Bank }\end{array}$ & $\begin{array}{l}\text { Investigation } \\
\text { launched in } \\
\text { April } 2018 \text { and } \\
\text { the report was } \\
\text { released in } \\
\text { October } 2018 .\end{array}$ & $\begin{array}{l}\text { Minister of Finance placed VBS under } \\
\text { curatorship with effect from } 11 \text { March 2018. In } \\
\text { April 2018, the Deputy Governor of the South } \\
\text { African Reserve Bank instituted an investigation } \\
\text { into VBS. The outcomes of the investigation } \\
\text { showed blatant fraud and corruption by senior } \\
\text { executives/Board and how they extracted } \\
\text { money from the bank. Municipal funds were } \\
\text { illegally deposited with VBS (senior ANC and } \\
\text { EFF politicians have been implicated). }\end{array}$ & $\begin{array}{l}\text { - SARB } \\
\text { investiga- } \\
\text { tion report } \\
\text { VBS Mutual } \\
\text { Bank - The } \\
\text { Great Bank } \\
\text { Heist }\end{array}$ & $\begin{array}{l}\text { - Several } \\
\text { Provincial and } \\
\text { Municipal } \\
\text { Officials } \\
\text { (Limpopo } \\
\text { Government) } \\
\text { - SOEs } \\
\text { (particularly } \\
\text { PRASA) }\end{array}$ \\
\hline $\begin{array}{l}\text { SA Institute } \\
\text { of Chartered } \\
\text { Accountants' } \\
\text { (SAICA) } \\
\text { investigation } \\
\text { into KPMG }\end{array}$ & $\begin{array}{l}\text { Final report was } \\
\text { handed to SAICA in } \\
\text { December } 2018 .\end{array}$ & $\begin{array}{l}\text { SA Institute of Chartered Accountants (SAICA) } \\
\text { established an Inquiry to investigate state } \\
\text { capture related allegations of misconduct of its } \\
\text { members who worked for KPMG. The Inquiry } \\
\text { chaired by advocate Dumisa Ntsebeza held } \\
\text { public hearings and handed its final report to } \\
\text { SAICA in December 2018. Indications are that } \\
\text { the final report will not be made public until all } \\
\text { investigations and disciplinary hearings have } \\
\text { been finalised. }\end{array}$ & - SAICA & - Guptas \\
\hline Bell Pottinger & $\begin{array}{l}2017 \text { investigation } \\
\text { by PRCA. }\end{array}$ & $\begin{array}{l}\text { In 2016, the Guptas appointed British PR } \\
\text { company, Bell Pottinger, who developed and } \\
\text { promoted a campaign that underpinned the RET } \\
\text { and WMC narratives. In 2017, there was an } \\
\text { independent law firm review by Herbert Smith } \\
\text { Freehills resulting in Bell Pottinger's expulsion } \\
\text { from the Public Relations and Communications } \\
\text { Association (PRCA). }\end{array}$ & $\begin{array}{l}\text { - PRCA } \\
\text { - GuptaLeaks } \\
\text { - Ongoing } \\
\text { research } \\
\text { on disinfor- } \\
\text { mation }\end{array}$ & - Guptas \\
\hline
\end{tabular}

